\title{
Chinese herbal medicine exhibits anticancer properties via eight cancer hallmarks
}

\author{
Menaga Subramaniam ${ }^{1}$, Yang Mooi $\operatorname{Lim}^{1,2^{*}}$ \\ ${ }^{1}$ Centre for Cancer Research, Faculty of Medicine and Health Sciences, Universiti Tunku Abdul Rahman, Kajang, Malaysia. \\ ${ }^{2}$ Department of Pre-clinical Sciences, Faculty of Medicine and Health Sciences, Universiti Tunku Abdul Rahman, Kajang, Malaysia.
}

\section{ARTICLE INFO \\ Received on: 21/02/2020 \\ Accepted on: 12/06/2020 \\ Available online: 05/08/2020}

Key words:

Chinese herbal medicine, cancer, antitumor, cancer hallmark.

\begin{abstract}
Chinese herbal medicine (CHM) is the key component of health care in China for the past 5,000 years. It has extensively influenced the healthcare industry not only in China but also in neighboring countries. The use of CHM to treat human diseases, especially cancer, is keep growing. Furthermore, millions of money were invested to study the role of CHM in cancer cure. In the last decade, researchers together with CHM practitioners tried to bridge the gap to understand each other's perspective to find the effectiveness of CHM in treating cancer. The mechanism of CHM in treating cancer is best understood via the theory of cancer hallmark proposed by Hanahan and Weinberg, which describes functional, molecular, and biological traits of specific cancer. The eight hallmarks of cancer are inhibiting proliferative signaling, inducing growth suppressors, inducing cell death, inhibiting replicative immortality, antiangiogenesis, inhibition of invasion and metastasis, energy metabolism, and immune destructive. The information is extracted from electronic resources (PubMed, Wiley, Springer, and ScienceDirect). This article reviews the antitumor activity of CHM against various cancers through each of the eight cancer hallmarks. It is hoped that this article would provide essential knowledge in cancer treatment by CHM.
\end{abstract}

\section{INTRODUCTION}

Cancer is a phenomenon when abnormal cells begin to grow out of control and end up in spreading to a distant region. Worldwide, the incidence of cancers is among the leading causes of morbidity and mortality, with approximately 14 million new cases and 8.2 million cancer-related deaths in 2012. The number of new cases expected to increase to 22 million within the next two decades (Stewart and Wild, 2014). Anticancer drugs are an important means to mitigate the impact of cancer mortality. Cancer treatment can be categorized into conventional (chemotherapy, radiation therapy, and surgery) and modern therapies (molecularly targeted therapy and immunotherapy). Lately, a holistic way of cancer treatment receives equal attention to treat this deadly disease. As such, the Chinese

\footnotetext{
"Corresponding Author

Yang Mooi Lim, Centre for Cancer Research, Faculty of Medicine and Health Sciences, Universiti Tunku Abdul Rahman, Kajang, Malaysia; Department of Pre-clinical Sciences, Faculty of Medicine and Health Sciences, Universiti Tunku Abdul Rahman, Kajang, Malaysia. E-mail:ymlim@utar.edu.my
}

herbal medicine (CHM) plays a significant role in cancer treatment. Asian countries such as China, Japan, and Korea have been using CHM for thousands of years mainly because they are naturally available and less toxic to normal cells (Mishra and Tiwari, 2011).

A very long history of CHM practice in cancer therapy has started in the last 2,000 years. An important proof was documented first in the classical works, such as The Yellow Emperor's Inner Canon and The Classic of Medical Problems (Liu et al., 2015; Wang, 2003). CHM practitioners follow merely the same approach to treat or manage cancer patients. The treatment is focused on strengthening body resistance, eliminating pathogens, and treating both the manifestation and root cause. Apart from that, they also practice treating the same disease with different methods and treating different diseases with the same method based on symptoms and signs. For example, treating patients with the common cold is not identical in CHM principle. Common cold is usually further divided into two types of syndrome: either caused by wind heat or wind cold. Herbs, pungent in flavor and cool in property, can relieve the wind heat, whereas herbs, pungent in flavor and warm in property, relieves wind cold. Next, chronic dysentery and prolapse of the rectum and uterus are two different 
diseases, but both exhibit the same syndrome of sinking MiddleQi. Therefore, according to the CHM concept, both can be treated with identical therapeutic to elevate Middle-Qi (Chan and Lee, 2002). These concepts of diagnosis and treatments have been proved by clinical practice (Liu et al., 2015).

Many CHM-derived anticancer drugs have been used in Western medicine. Between 1940 and 2014, around 49\% of approved cancer chemotherapeutic drugs are derived from natural products (Newman and Cragg, 2016). Vinblastine, vincristine, paclitaxel, camptothecin, and epipodophyllotoxin are few examples of plant-derived CHMs that have been used in Western medicine (Pereira et al., 2012). Millions of people around the world have been accepting and using CHM. It is not only used as standalone therapy but often used as an adjuvant or in combination with other therapies to improve health. Undoubtedly, CHM is a valuable resource to discover novel anticancer agents.

\section{ROLE OF CHM IN TREATING VARIOUS DISEASES}

CHM utilizes a unique approach by combining the advantages of physiological and holistic theories. Its prime method to heal patients is by modulating and exploiting interactions between the patients and their environment. Therefore, it is important to understand the patient's environment and herbal formulae in CHM perspectives. In this holistic approach, the human's health system is explained based on ancient theory "Qi," which said that the life force energy is carried in the body via meridians. Qi is said to be responsible for physiological functions. Any disruption in Qi ultimately results in disharmony in the body such as disruptions to homeostasis and diseases. In the event of disruption in Qi, CHM aims to address these imbalances to enable the body to heal itself(Li and Zhao, 2012).

The principle of CHM explains that herbal formulae consist of four elements. First, the monarch (Jun) that aims at the cardinal pathological of a disease. Second, the minister (Chen) that helps monarch to treat secondary symptoms. Next, assistant (Zuo) and servant (Shi) both are mainly coordinate the formulae, facilitate the first two elements, and decrease their side effects. All the elements eventually help each other to maintain harmonious of body to achieve an ideal therapeutic outcome (Zhou et al., 2016).

CHM was used in various diseases such as hypertension (Lu et al., 2007), coronary heart (Jian et al., 2010), and rheumatoid arthritis (Lu et al., 2010) or biomedical conditions such as neuroendocrine-immune network ( $\mathrm{Li}$ et al., 2007) including cancer for more than hundred years. Today, there are many options available to treat cancer including surgery, radiation, chemotherapy, immunotherapy, hormonal therapy, targeted therapy, and many more. Among them, herbal medicine is emerging as an important alternative therapy in cancer treatment. This ancient therapy not only plays a key role in prevention but also has been reported to enhance pain management and to improve the lifespan(Ritenbaugh et al., 2012).

A special characteristic of CHM is utilizing the precision medicine concept. The ideology of this treatment is based on the right patient, right diagnosis, and right treatment with the right amount of drug to treat the disease efficiently. Even though this concept is well established in CHM practice, its role as precision medicine was only emerged recently worldwide. A great evolution started when President Obama announced the launch of new
Precision Medicine Initiative (Fox, 2015) in the State of the Union address, in which he has mentioned that every patient is unique, and it is essential that they are tailored with individual treatment. Currently, efforts are taken to evaluate CHM's efficacy in cancer treatment by utilizing pharmaceutical-based approaches to reveal the mode of actions at molecular levels.

\section{MODE OF ACTION: HOW CHM REGRESSES CANCER}

A large number of studies show that the multitargeted nature of CHM may comprise multiple herbs and components acting simultaneously on multiple cellular mechanisms and molecular targets that derived from its biological compounds (Yoo et al., 2018). CHM contains many active compounds that can target the eight hallmarks of cancer. The eight hallmarks of cancer shown in Figure 1 are inhibiting proliferative signaling, inducing growth suppressors, inducing cell death, inhibiting replicative immortality, antiangiogenesis, inhibition of invasion and metastasis, energy metabolism, and immune destructive (Hanahan and Weinberg, 2011).

\section{Antiangiogenesis}

Angiogenesis is a process to form a new blood vascular system around the cells and tissues. When normal cells require nutrient and oxygen to remove metabolic waste products, angiogenesis will occur. In the normal human body, during embryogenesis, formation of new endothelial cells and surrounded vascular allows sprouting of new vessels from the existing ones. Angiogenesis is constitutively activated in normal cells during wound healing and female menstrual cycle. However, in highly proliferative cancer cells, angiogenesis is always activated to support neoplastic growth and tumor progression (Hanahan and Folkman, 1996).

Angiogenesis in tumor environment ensures continuous supply of nutrient and oxygen and elimination of carbon dioxide and waste materials from neoplastic cells. Pro- and antiangiogenesis factors from tumor microenvironment control the formation of vascularization. As shown in Figure 2, binding of pro-angiogenesis factors to cell receptors induces growth, proliferation, and formation of tubules, whereas binding of antiangiogenesis factors activates caspases, which leads to apoptotic cell death. The well-known angiogenesis inducer is vascular endothelial growth factor (VEGF). Basic fibroblast growth factor (bFGF and FGF2), angiogenin, transforming growth factor (TGF)- $\alpha$, TGF- $\beta$, tumor necrosis factor (TNF)- $\alpha$, platelet-derived endothelial growth factor, granulocyte colony-stimulating factor, placental growth factor, interleukin-8, hepatocyte growth factor, and epidermal growth factors are among other commonly listed inducers (Mousa and Davis, 2016). Negative regulators such as thrombospondin, angiostatin, endostatin, interferon, platelet factor 4, prolactin 16-kd fragment, and tissue inhibitor of metalloproteinase-1, -2 , and -3 also play a critical role in controlling angiogenesis (Nishida et al., 2006). When tumor cells demand nutrient and oxygen, angiogenesis is activated; angiogenic activators are upregulated, whereas negative regulators will be downregulated. A balance between these two types of markers is vital to control vascular homeostasis or angiogenesis.

CHM inhibits cancer development and progression by altering tumor microenvironment and by directly inhibiting angiogenesis and lymphangiogenesis. Extract from Ginkgo 


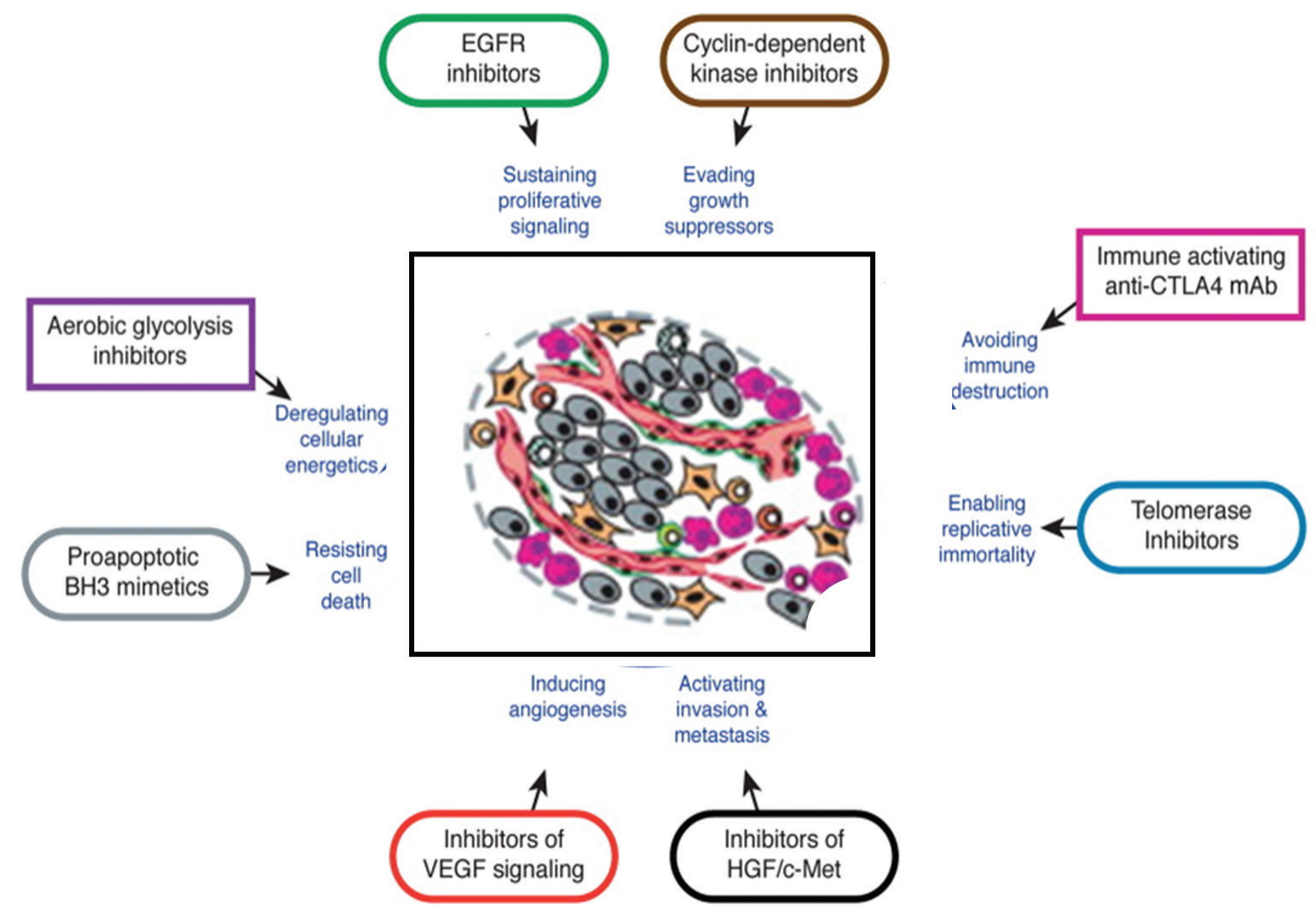

Figure 1. The hallmarks of cancer. This illustration encompasses the eight hallmarks of cancer proposed by Hanahan and Weinberg in 2011 (Hanahan and Weinberg, 2011).

biloba was reported to show inhibitory effects in in vitro and in vivo against multiple cancers such as ovarian (Ye et al., 2007), breast (Papadopoulos et al., 2000), hepatocellular (Chao and Chu, 2004), and oral (Kim et al., 2005). Scutellaria barbata D. Don is another CHM that proved to suppress angiogenesis in colon cancer by downregulating VEGF- $\alpha$ (Wei et al., 2011). It has been used in clinical trials, revealed to be safe and well-tolerated, and showed promising clinical evidence against metastatic breast cancer patients (Perez et al., 2010). The Yangzheng Xiaoji (YZXJ) capsule, derived from a CHM formula, exhibited anticancer actions on primary hepatic carcinoma (Zhang et al., 2009). This capsule contains the following 16 ingredients: Panax ginseng C.A. Mey., Astragalus membranaceus (Fisch.) Bge.var. mongholicus (Bge.) Hsiao, Ligustrum lucidum Ait., Curcuma phaeocaulis Val., Ganodema lucidum, Gynostemma pentaphylla (Thunb) Mak, Atractylodes macrocephala Koidz., S. barbata D. Don, Oldenlandia diffusa (Willd.) Roxb., Poria cocos, Duchesnea indica Focke, Solanum lyratum Thunb., Artemisia scoparia (Bge.) Ki., Cynanchum paniculatum Kitag, Eupolyphaga sinensis Walker, and Gallus domesticus Brisson. YZXJ was demonstrated to inhibit angiogenesis by directly targeting endothelial cells and significantly affect endothelial tubule formation, migration, and cell matrix attachment (Jiang et al., 2012). Ginsenoside Rg3, a pure compound extracted from ginseng (Lu et al., 2009; Zheng et al., 2014), showed an antiangiogenic effect in colorectal cancer. It was executed by downregulating the expression of 22 proangiogenic-related genes (Tang et al., 2017). The antiangiogenesis effect of $\operatorname{Rg} 3$ was also reported in glioblastoma (Sun et al., 2016).

\section{Inhibit invasion and metastasis}

Tumor microenvironment is made up of complex nonmalignant cells such as endothelial, pericytes, fibroblasts, and immune cells that surround cancer cells (Jia et al., 2012). The tumor environment largely depends on signals including tumor promoter and tumor suppressor produced from these various cells. CHM has been shown to control tumor environment by inhibiting tumorpromoting signals while inducing the production of cytokines to suppress tumor development. Matrix metalloproteinases (MMPs) are enzymes that activate tumor microenvironment to undergo metastasis, spreading of tumor cells from the primary sites. Highly expressed MMPs often result in poor clinical outcome due to cell invasiveness and metastasis (Sherman-Baust et al., 2003). Several studies showed CHM's ability to inhibit MMP expression in cancer environment upon treatment. A standard formulation of Si-Jun-Zi-Tang (composed of four Chinese herbs: ginseng root, A. macrocephala, licorice root, and poria root) with the addition of Myristica fragrans and five-leaf akebia fruit (known as Yi-Qi-Fu-Sheng) has shown to initiate ERK1/2-dependent inhibition of MMP-2/9 expression. By selectively targeting ERK phosphorylation, this decoction modulates the REK/Mitogenactivated protein kinases (MAPK) pathway and its downstream factors (Deng et al., 2013). Other Chinese herbs that can promote anti-invasiveness by controlling the inhibition and regression of MMPs are Mu BieZi (Momordica cochinchinensis)(Zheng et al., 2014). Artemisinin, which is an active compound from Chinese wormwood (Artemisia absinthium), acts by lowering both VEGF and its receptors (Efferth et al., 2002), turmeric (Curcuma longa) 


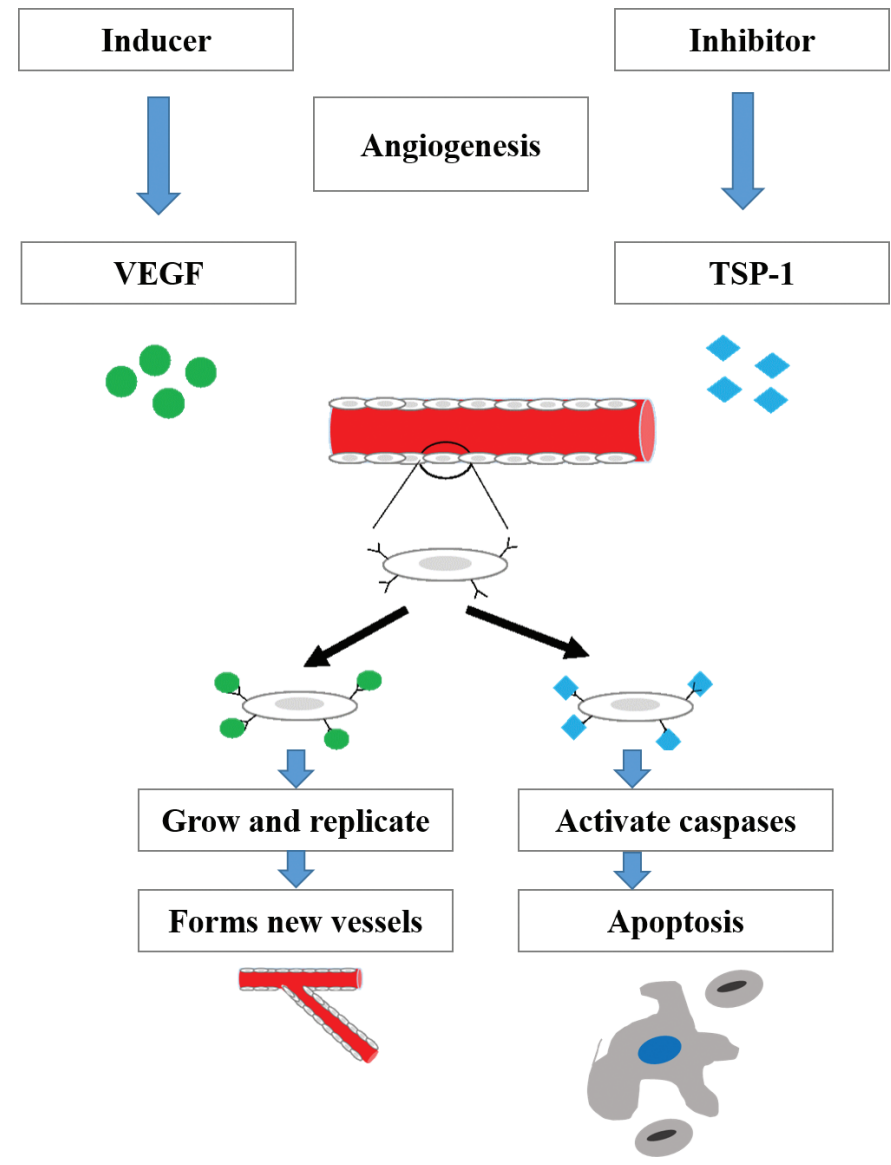

Figure 2. Role of pro- and antiangiogenesis factors on vascularization. VEGF binds to its receptors on endothelial cells to initiate a break through existing blood vessels, grow and migrate to form new blood vessels. Binding of inhibitors to the receptors triggers the activation of caspases to activate apoptosis.

(Arbiser et al., 1998), and Scutellaria Baicalensis (Yance et al., 2006).

\section{Antiproliferative signaling}

Proliferation is a natural phenomenon in normal cells to rapidly reproduce cells, tissues, or organism. An uncontrolled cell division increases the proliferation rate to form malignant tumor. Proliferation has become an important event of cancer development and progression. Cell-cycle mechanism is a process where cells actively divide in several phases. Each phase of the cell cycle is tightly regulated, and the damaged cells are immediately removed before entering the next phase to avoid genetic mutation. Dysregulated expression of cell-cycle proteins ( $\mathrm{Rb}, \mathrm{CDKs}$, and CDK inhibitors) promotes uncontrolled cell proliferation. Apart from cell-cycle proteins, there are other proteins such as Akt, PI3kinase, and Rat sarcoma involved in directing the proliferation and constitutive activation of multiple signaling pathways (Hanahan and Weinberg, 2011; Liebermann et al., 2007; Wang et al., 2015). A number of studies have shown that the dysfunction of cell-cycle regulation and proliferation receptors often results in cancer progression (Hsu et al., 2013). Therefore, a compound that can stop excessive proliferation leads to inhibition of cancer development. Previous studies reported that CHM-based compounds and decoctions can act as antiproliferative agents in cancer treatment. For example, Xiaoji Decoction (composed of Coriolus Versicolor, Psoralea Corylifolia L., Hedyotis Diffusa, Astragalus Mongholicus, Scorpion, Centipede, and Rhubarb) inhibits proliferation of lung cancer cell line via Akt pathway by upregulating the expression of $\mathrm{Bcl}-2$-associated death promoter and caspase-9 (Chai et al., 2014). M. cochinchinensis seeds were also reported to have antiproliferative activity on various human lung cancer cell lines, such as A549, H1264, H1299, and Calu-6 (Yu et al., 2017). Marsdenia tenacissima extract inhibits proliferation of esophageal carcinoma via MAPK pathway (Fan et al., 2015). A synergistic combination of Rosa roxburghii Tratt and Fagopyrum cymosum significantly inhibits proliferation and activates apoptosis against human esophageal squamous carcinoma CaEs-17. The protein expression level of Ki-67 and Bcl-2 was greatly decreased, whereas the expression of Bax was markedly increased (Liu et al., 2012). Bufalin, an active compound extracted from the dried toad skin, induces G2/M phase arrest in liver cancer (Hsu et al., 2013). Apart from common cancers, CHMs also have shown to affect the proliferation of gastric cancer cell lines. Sanpi Pingwei formula was reported to inhibit proliferation as well as induce apoptosis in SGC-7901 gastric cell line. This formula targets the main channel such as Bax, p53, and Bcl-2. Upregulation of p53 and a decrease in Bcl-2 levels control proliferation upon treatment (Dang et al., 2013). Similarly, upon exposure of arsenic sulfide, the main component of realgar, a CHM was showed to induce apoptosis in AGS gastric cells by targeting p53 expression (Zhang et al., 2014). Jianpi Huayu decoction, a Chinese medicine formula, inhibited proliferation in SW480 colorectal cells by inducing $\mathrm{G}_{\mathrm{o}} / \mathrm{G} 1$-phase cell-cycle arrest and apoptosis. Besides, this decoction also enhanced the expression of p27, cleaved poly (ADP-ribose) polymerase, cleaved caspase-3, and Bax while reducing the level of Bcl-2 and various cyclins (Xi et al., 2015). Emodin, a natural compound extracted from various Chinese herbal plants, including Rheum officinale and Polygonum cuspidatum (Ma and Li, 2012), inhibits proliferation of colorectal cancer cell line LOVO by inducing mitochondrial-mediated apoptosis via upregulating expression of Bax and downregulating Bcl-2 expression (Ma and Li, 2014). Figure 3 shows the summary of reported antiproliferative actions of CHM.

\section{Antigrowth suppressor}

Many programs in cancer cells help in proliferation to ensure the formation of tumor without interruption. When these programs are negatively regulating cell proliferation, it will control cancer progression and ultimately prevent tumor formation. These programs are mainly activated by tumor suppressor proteins. They play important roles in suppressing uncontrolled proliferation, immortality, and tumorgenicity. The two main tumor suppressors are retinoblastoma susceptibility gene $(\mathrm{RB})$ and $\mathrm{p} 53$ proteins. $\mathrm{RB}$ is a negative regulator of the cell cycle that inhibits both $\mathrm{G}_{1}$ and S-phase progression (Bartek et al., 1997). RB (unphosphorylated or hypo-phosphorylated) suppresses cell cycle progression by binding to transcription factors such as E2f1 (transcription factor 1) to inhibit their activation. The phosphorylation of RB-E2f1 complex leads to dissociation and consequently enters S-phase (Cobrinik et al., 2005; Martin and Gerd, 2017). Apart from controlling cell cycle regulation, RB also controls other cellular 
processes such as differentiation (Lipinski et al., 1999), senescence (Dasgupta et al., 2006), and apoptosis (Chau and Wang, 2003).

p53, a tumor suppressor, controls various genetic expression, cell proliferation, and modulation of signal transduction pathway. During DNA damage in a cell, p53 will be accumulated to initiate cell arrest and trigger apoptosis to control abnormal cell proliferation. Besides, p53 is also involved in DNA repair to prevent the accumulation of mutation and suppresses tumor development (O'Neil and Rose, 2006). Other examples of tumor suppressors include phosphatase and tensin homolog (PTEN) (phosphatase and tensin homolog on chromosome 10), p21WAF1, p27KIP1, and adenomatosis polyposis coli (APC) (adenomatosis polyposis coli). As shown in Figure 4, the accumulation of p53 induces p21WAF1/ p27KIP1 to initiate cell cycle arrest, whereas APC a multidomain

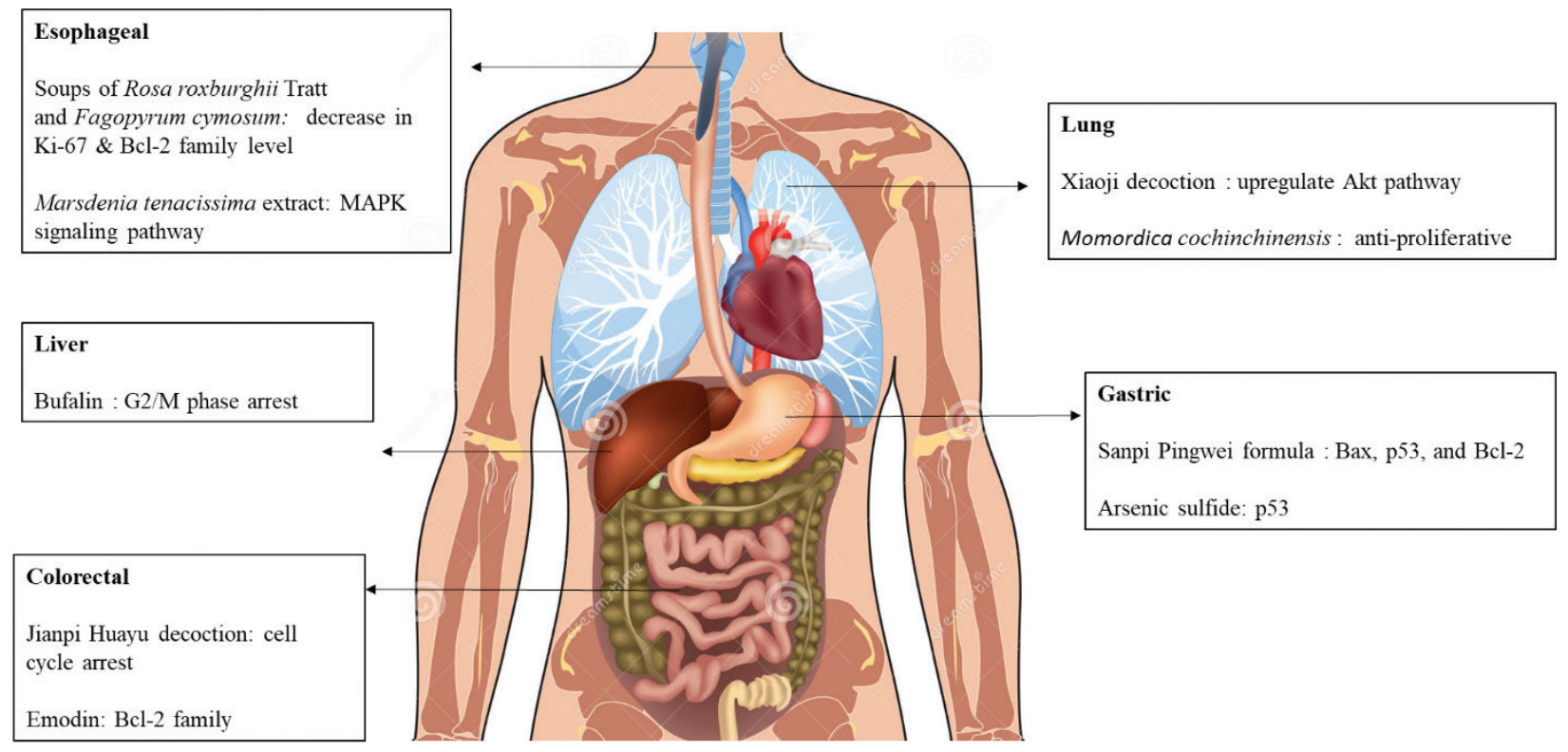

Figure 3. Antiproliferative actions of CHM against human cancers and its targets.

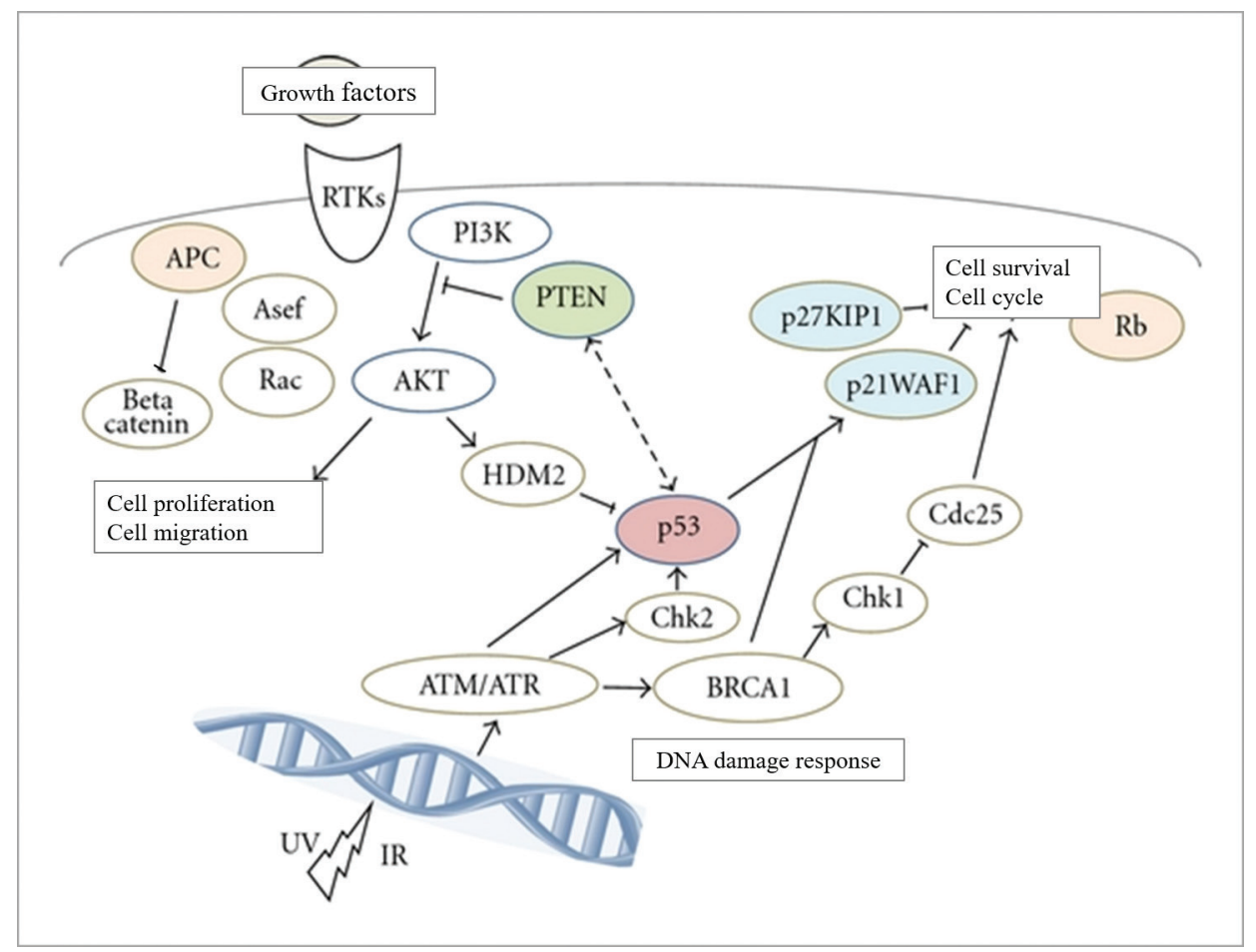

Figure 4. Schematic representation of tumor suppressor signaling including p53, Rb, APC, p21WAF1/p27KIP1, and PTEN. Examples of molecules known to act on cell proliferation and cell survival via the regulatory pathways are shown (Adapted from Kitagishi et al., 2012). 
protein, through which it binds to various binding proteins such as beta-catenin, Asef, and Rac, leads to the prevention of cancer cell overgrowth (Kitagishi et al., 2012).

Several studies revealed the role of CHM in tumor suppression. Chinese herbal formula, Yangyinjiedu, inhibits the proliferation of lung cancer cell lines (95-D, A549, H460, and H1975) by inducing cell cycle arrest and senescence via an elevated level of p53 (Zheng et al., 2017). Kanglaite (KLT), an extract from Coix seed, induces apoptosis of tumor cell by increasing the mRNA level of p53 (Lu et al., 2008). Honokial, a component of oriental herb Magnolia officinalis, significantly reduces the level of $\mathrm{Rb}$ protein in prostate cancer cells (Hahm et al., 2007). It also reduces the PTEN protein level in adipocyte cancer by controlling angiogenic activity (Liu et al., 2008). Similarly, Acanthopanax gracilistylus inhibits the proliferation of MT-2, Raji, HL-60, TMK-1, and HSC-2 through cell cycle arrest accompanied by a decreased phosphorylated level of pRb (Shan et al., 2000). Liposome-encapsulated curcumin and resveratrol in combination reported to effectively inhibit cell growth and to induce apoptosis. The finding also confirms that the cell death of prostate cancer was due to the loss of PTEN suppressor (Narayanan et al., 2009). Carnosol, a constituent from rosemary herb, has shown to prevent APC-associated intestinal tumorigenesis by increasing E-cadherinmediated adhesion and suppression of beta-catenin tyrosine phosphorylation (Moran et al., 2005). APC-mediated suppression was also reported in human cervical cancer cells such as Caski and HeLa on exposure with trichosanthin. Trichosanthin is a main bioactive component from CHM, the root tuber of Trichosanthes kirilowii Maxim. In a study done by Huang (Huang et al., 2012), trichosanthin showed to inhibit DNA methyltransferase and restore the expression of methylation-silenced tumor suppressor genes. Therefore, it was categorized as potentially useful demethylation agent for the clinical treatment of human cervical cancer. An extract of Magnolia inhibits the proliferation of urinary cancer cells via G1 cell cycle arrest. Post-treatment and expression of p21WAF1 and p27KIP1 were reported to be upregulated. They were also believed to interact with cell cycle proteins, CDKs, and nuclear antigens to form complex, which trigger the prevention of cell proliferation. Similarly, baicalin, a flavonoid compound extracted from the root of $S$. baicalensis Georgi, reported to inhibit the proliferation of prostate cancer cells such as PC-3 and LN-CaP by activating the expression of cyclin-dependent kinase inhibitor, $\mathrm{p} 27 \mathrm{KIP} 1$. Table 1 shows the role of CHM and active compound as a tumor suppressor.

\section{Cell death}

In early 2018, Galluzzi(Galluzzi et al., 2018) highlighted 14 different types of cell death such as intrinsic apoptosis, extrinsic apoptosis, mitochondrial permeability transition - driven necrosis, necroptosis, ferroptosis, pyroptosis, parthanatos, entotic, NETotic, lysosome-dependent, autophagy-dependent, immunogenic, cellular senescence, and mitotic catastrophe. Among them, three major cell deaths are apoptosis, autophagy, and necrosis. The role of CHM against these cell deaths will be discussed in this session.

Apoptosis has taken the central stage as the principal mechanism of programmed cell death (PCD). PCD basically refers to its strong genetic controls (Daniel and Korsmeyer, 2004) where it ends up in the disintegration of cellular components and engulfment by surrounding cells. Apoptosis is a biochemical event involving cell membrane blebbing, shrinkage, chromatin condensation, and nucleosomal fragmentation (Kroemer et al., 2008). Apoptosis is classified as a major mechanism of chemotherapy-induced cell death. Therefore, cytotoxic agents/drugs that target this pathway are the main focus of many preclinical discovery investigations. Apoptosis can be further divided into intrinsic and extrinsic apoptosis. These two pathways are controlled by its own initiator caspases (intrinsic apoptosis govern by caspase-9 and extrinsic apoptosis initiated by caspase-8) and follow similar execution pathways via caspase 3 .

Ursolic acid is an active ingredient found in several CHMs, such as O. diffusa (Willd.) Roxb. and L. lucidum W.T. Aiton. It was showed to induce cancer cell death via caspasedependent pathway in prostate cancer cells (Kwon et al., 2010). This active compound has elevated caspase- 9 and caspase- 3 levels in prostate cancer cells. In general, the activation of intrinsic apoptosis involves the release of cytochrome-c from mitochondria, apaf-1, and apoptosome formation before it enters into the cascade of caspase activation. Other CHMs such as Aloe emodin (Dong et al., 2010), artemisinins (Chen et al., 2017), arsenic trioxide (Lam et al., 2005), baicalin (Peng et al., 2015), hesperetin (Palit et al., 2015), and matrine (Zhang et al., 2012) were also reported to induce mitochondrial-mediated apoptosis.

While intrinsic apoptosis mediated by internal organelle (mitochondria), external apoptosis involves the binding of death ligands (Fas and FasL) at cellular membrane to facilitate apoptosis. Oridonin (Kang et al., 2010), polyphenols from green tea $(\mathrm{Oz}$ et al., 2010; Tsukamoto et al., 2012), and glycyrrhizin (Haghshenas et al., 2014) are the examples of CHM, which target cancer cell death via this pathway.

Autophagy is also a genetically controlled cell death and classified under PCD. It is activated during essential nutrient starvation such as carbon and amino acid, resulting in intracellular component degradation. During autophagy, autophagosomes in cytoplasm combine with the key organelle, lysosome. On fusion, the release of lysosomal hydrolases allows the degradation of misfolded proteins and organelles (Shintani et al., 2004). The presence of beclin one protein indicates the activation of autophagy. Anticancer drug combination of Sun-Bai Pi extract with commercial drug cisplatin was reported to synergistically kill non-small cell lung cancer and allows rapid low-dose cancer cell elimination via autophagy cell death (Tseng et al., 2016).

Next, necrosis is most likely controlled by signal transduction pathways and catabolic mechanisms. Its features include translucent cytoplasm, swollen organelles, dilatation of nuclear membrane, chromatin condensation, and increased cell volume (Vandenabeele et al., 2010). In cancer cell, imbalance of intracellular calcium flux, reactive oxygen species (ROS) generation, and activation of non-apoptotic proteases influence each other to activate necrosis. Cell dying via necrotic death initiates pro-inflammatory signals to release inflammatory cytokines and spill their content during lyses. Due to this, necrosis is considered to be a more harmful way for a cell to die compared with apoptosis. However, very less CHMs were reported to induce necrotic cell death. Shikonin from Lithospermum erythrorhizon Siebold was showed to induce necrosis in MCF-7 and HEK293 cells (Han et al., 2007; Han et al., 2009). Interestingly, Han (Han 
Table 1. The role of CHM and active compound as tumour suppressor.

\begin{tabular}{|c|c|c|c|c|c|c|}
\hline $\begin{array}{l}\text { Tumour suppressor } \\
\text { genes }\end{array}$ & $\begin{array}{l}\text { CHM \& active } \\
\text { compound }\end{array}$ & Plant source/part & Cancer type & Cell line & Mechanism of action & Reference \\
\hline \multirow[t]{9}{*}{ p53 } & \multirow[t]{3}{*}{ S. baicalensis } & \multirow[t]{3}{*}{ Root } & \multirow[t]{3}{*}{ Lung } & A549, & Cell growth arrest & \multirow[t]{3}{*}{ (Gao et al., 2011) } \\
\hline & & & & SK-LU-1 & Apoptosis & \\
\hline & & & & SK-MES-1 & & \\
\hline & \multirow[t]{2}{*}{ Gleditsia sinensis } & \multirow[t]{2}{*}{ Thorn } & \multirow[t]{2}{*}{ Colon } & \multirow[t]{2}{*}{ HCT116 } & Cell growth & \multirow[t]{2}{*}{ (Lee et al., 2010) } \\
\hline & & & & & Cell cycle arrest & \\
\hline & KLT & Coix seed & $\begin{array}{l}\text { Non-small-cell lung } \\
\text { cancer }\end{array}$ & A549 & Apoptosis & (Lu et al., 2010) \\
\hline & \multirow[t]{2}{*}{ Ginsenoside } & \multirow[t]{2}{*}{ Ginseng root } & \multirow[t]{2}{*}{ Colorectal } & \multirow[t]{2}{*}{ HCT116 SW480 } & Bax protein and & \multirow[t]{2}{*}{ (Li et al., 2011) } \\
\hline & & & & & induces cell death & \\
\hline & Thymoquinone & Black seed & Colorectal & HCT-116 & Apoptosis & (Gali-Muhtasib et al., 2004) \\
\hline \multirow[t]{12}{*}{$\mathrm{Rb}$} & \multirow[t]{2}{*}{ Honokiol } & \multirow[t]{2}{*}{ M. officinalis } & \multirow[t]{2}{*}{ Prostate } & PC-3 & \multirow[t]{2}{*}{ Cell cycle arrest } & \multirow[t]{2}{*}{ (Hahm et al., 2007) } \\
\hline & & & & $\mathrm{LNCaP}$ & & \\
\hline & \multirow[t]{5}{*}{ A. gracilistylus } & \multirow[t]{5}{*}{ Dried barks } & \multirow[t]{3}{*}{ Leukemia } & MT-2 & \multirow{5}{*}{$\begin{array}{l}\text { Inhibit proliferation via } \\
\text { cell cycle arrest }\end{array}$} & \multirow[t]{5}{*}{ (Shan et al., 2000) } \\
\hline & & & & Raji & & \\
\hline & & & & HL-60 & & \\
\hline & & & Stomach & TMK-1 & & \\
\hline & & & Oral & HSC-2 & & \\
\hline & \multirow[t]{4}{*}{ Licochalcone } & root & Prostate & PC-3 & Anti-proliferation & (Fu et al., 2004) \\
\hline & & & Gastric & MKN-28 & Reduces expression & (Xiao et al., 2011) \\
\hline & & & & AGS & & \\
\hline & & & & $\mathrm{MKN}-45$ & $\begin{array}{l}\text { and Cdk6. inhibits } \\
\text { phosphorylation of S780 }\end{array}$ & \\
\hline & Zyflamend & $\begin{array}{l}\text { Rosemary, turmeric, } \\
\text { ginger, holy basil, } \\
\text { green tea, hu zhang, } \\
\text { Chinese goldthread, } \\
\text { barberry, oregano, } \\
\text { baikal skullcap }\end{array}$ & Prostate & PC-3 & Anti-inflammatory & (Yang et al., 2007) \\
\hline PTEN & Honokiol & Magnolia species & Adipocytes & 3T3-L1 & Angiogenic activity & (Liu et al., 2008) \\
\hline & & & & & & (Yang et al., 2008) \\
\hline & & & Breast & BT-474 & & \\
\hline & Curcumin and & Turmeric & Prostate & PTEN-CaP8 & Apoptosis & (Narayanan et al., 2009) \\
\hline & & Japanese knotweed & & & & \\
\hline & Rosemary extract & Rosemary herb & Myeloid cell & K562 & Repress PTEN expression & (Yoshida et al., 2011) \\
\hline p21WAF1 & Aqueous extract of & Magnolia officinalis & Urinary cancer & 5637 & Anti-proliferation & (Lee et al., 2007) \\
\hline p27KIP1 & & & & & G1 cell cycle arrest & \\
\hline & Baicalin & Root of $S$ & Prostate cancer & LNCaP & Apoptosis & (Dong et al., 2010) \\
\hline & & baicalensis Georgi & & $\mathrm{PC} 3$ & Anti-proliferation & \\
\hline & G. sinensis & Thorns & $\begin{array}{l}\text { Vascular smooth } \\
\text { muscle cells }\end{array}$ & VSMC & Cell cycle arrest & (Lee et al., 2012) \\
\hline & Saussurea involucratat & $\begin{array}{l}\text { Aerial part including } \\
\text { flower }\end{array}$ & Prostate & $\mathrm{PC}-3$ & $\begin{array}{l}\text { G1 phase cell cycle arrest } \\
\text { and apoptosis }\end{array}$ & (Way et al., 2010) \\
\hline $\mathrm{APC}$ & Tichosanthin & $\begin{array}{l}\text { T. kirilowii } \\
\text { Maximowicz }\end{array}$ & Cervical & $\mathrm{HeLa}$ & Demethylation & (Huang et al., 2012) \\
\hline & Carnosol & Rosemary & Intestinal cancer & $\begin{array}{l}\mathrm{C} 57 \mathrm{BL} / 6 \mathrm{~J} / \mathrm{Min} /+(\mathrm{Min} /+) \\
\text { mouse }\end{array}$ & $\begin{array}{l}\text { Enhance E-cadherin- } \\
\text { mediated adhesion }\end{array}$ & (Moran et al., 2005) \\
\hline & & & & & $\begin{array}{l}\text { Suppress beta-catenin } \\
\text { tyrosine phosphorylation }\end{array}$ & \\
\hline
\end{tabular}


et al., 2009) further stated the presence of necrostatin-1 (Nec-1), a specific necroptosis inhibitor, that can revert back necrosis to apoptosis. This switch mode is associated with Bax translocation partially due to the conversion of mitochondrial inner membrane permeability to outer membranes. Their data also suggested that apoptosis and necroptosis may function as reciprocal backup mechanisms of cellular demise. Similarly, a synergistic combination of 5-FU with gambogenic acid against human lung cancer cells A549 was reported to induce a typical cellular necrotic death which was primarily necroptosis and posteriorly apoptosis (Su et al., 2014).

\section{Inhibit replicative immortality}

Normal cells are going through a limited number of growth and division. The cell cycle consists of four distinct stages: $\mathrm{M}, \mathrm{G}_{\mathrm{o}}, \mathrm{S}$, and $\mathrm{G} 1$ inclusive of two proliferation barriers: senescence and crisis. Under certain conditions, when normal cells skip these barriers, it reaches immortalized state. In normal cells, telomeres at the end of chromosome protect the DNA from instability and damages. When telomeres shorten progressively with each cell division, it damages the DNA. Therefore, successive cell division is correlated with the length of telomeric DNA. Telomerase is highly expressed in the majority of immortalized cells, and telomere repeat segment is added to the end of the DNA that helps to increase the cell cycle division which eventually will increase the resistance to cell death. In a nutshell, the activation of telomerase enzyme leads to the extension of telomere that could block apoptosis and promotes proliferation and tumor oncogenesis (Shay et al., 2011). It was reported that telomerase activity and malignancy have a close association. Therefore, targeting telomerase activity can be a promising cancer treatment.

Several studies have reported the use of CHM in targeting telomerase activity. Matrine, one of the main components extracted from a Chinese herb, Sophora flavescens Ait. (Leguminosae), was reported to have a significant effect on the inhibition of proliferation by suppressing telomerase activity in K562 cells (Zhang et al., 2001). In 2009, Wang (Wang et al., 2009) found that epigallocatechin gallate (EGCG), a major component of polyphenols in green tea, inhibits telomerase activity. They found that EGCG inhibited cell growth and induced apoptosis with an increase of caspase- 3 activity and downregulation of telomerase activity in a dose-dependent manner in Hep-2 cells. A further study revealed that EGCG directly inhibited the catalytic subunit of telomerase that blocks the transcription of telomerase reverse transcriptase (Meeran et al., 2010). The inhibition of telomerase activity was also observed in allicin (major compound found in crushed garlic)-treated gastric cancer SGC-7901 cells (Sun et al., 2003).

\section{Immune destructive}

In cancer initiation and progression, failure of host immune system plays a crucial role. A weaker immune system fails to recognize and eliminate the majority of neoplastic cells, thus resulting in progression and spreading to other organs. Repetitive chemotherapy and radiotherapy can also impair the immune system followed by bone marrow suppression (Fromenti et al., 2009; Meir et al., 2017).
In general, natural compounds inclusive of CHMs are believed to regulate the human immune system. They can enhance the immune response against the tumor, may suppress immune inhibitory responses, shift the immune system balance, and restore/reverse the impaired immune system to its normal condition (Haddad et al., 2005). During the activation of immune system, an increase in inflammatory $\mathrm{T}$ cells and natural killer $\mathrm{T}$ cells can be observed, whereas the reduction of regulatory $\mathrm{T}$ cells and myeloid-derived suppressor cells can also be seen. Apart from that, $\mathrm{CHM}$ also regulates cytokine productions such as IFN- $\alpha$, IL2, IL-6, and IFN- $\gamma$ to fight against tumor cells (Ma et al., 2008; Peng et al., 2013; Xiao et al., 2015).

The ability of CHMs in regulating patient's immune system is not new. Research findings proved that polysaccharide content found in CHM plays a main role to activate immune response. For example, treatment with Momordica charantia polysaccharide (Fang et al., 2012), Lycium barbarum polysaccharide, G. lucidum polysaccharides (Xu et al., 2011), and Acanthopanax senticosus polysaccharide and lentinan strengthen the immune system to inhibit tumor growth (Huyan et al., 2014). Next, Radix Astragali (RA), a popular CHM, is obtained from the dried root of $A$. membranaceus Bge. Var. mongholicus. The main active compounds of RA are polysaccharides $(6.83 \%-13.48 \%)$, saponins $(1.96 \%-3.58 \%)$, and flavonoids $(0.75 \%-1.49 \%)$ (Jung et al., 2016). It has been used as a tonic and known to enhance immune function by activating macrophages and natural killer cells (Cho et al., 2007). Apart from that, RA also shows immunomodulatory properties in combination with chemotherapy and radiotherapy (Monograph, 2003). Ginseng is a famous CHM that highly used among Asian. It shows anticancer and antiinflammatory properties and reduces cancer occurrence in gastric, liver, pancreatic, and colon by controlling host immune system (Hofseth and Wargovich, 2007; Yun and Choi, 1995).

\section{Energy metabolism}

Energy metabolism in normal cells occurs in aerobic and anaerobic conditions. In aerobic condition, the presence of oxygen allows glucose breakdown to pyruvate in the cytoplasm. Later, pyruvate with the help of oxygen breaks down in mitochondria to release carbon dioxide and 36 molecules of adenosine triphosphate (ATP). This phenomenon is known as oxidative phosphorylation. In anaerobic condition, normal cells undergo anaerobic glycolysis in the cytoplasm, where glucose converted to pyruvate then lactate. Anaerobic glycolysis produces less energy, which is only 2-ATP. In conclusion, normal cells select oxidative phosphorylation in the presence of oxygen to release high energy, whereas uses anaerobic glycolysis in the absence of oxygen to release less energy. Interestingly, this is not the norm in cancer cells (Fig. 5). Energy metabolism in cancer cells does not depend on aerobic or anaerobic conditions. Proliferative tissues or tumor consumes glucose to produce pyruvate and then converts it to mostly lactate even in the presence of ample of oxygen (DeBerardinis et al., 2008; Warburg, 1956). Cancer cell adaptation to this pathway is known as the Warburg effect or aerobic glycolysis which is critical for tumor cell growth, proliferation, angiogenesis, and stress resistance. As one of the hallmarks of cancer, active aerobic glycolysis by cancer cells has been utilized in the clinical sector as a means of diagnosis and monitoring cancer treatment response in positron emission 


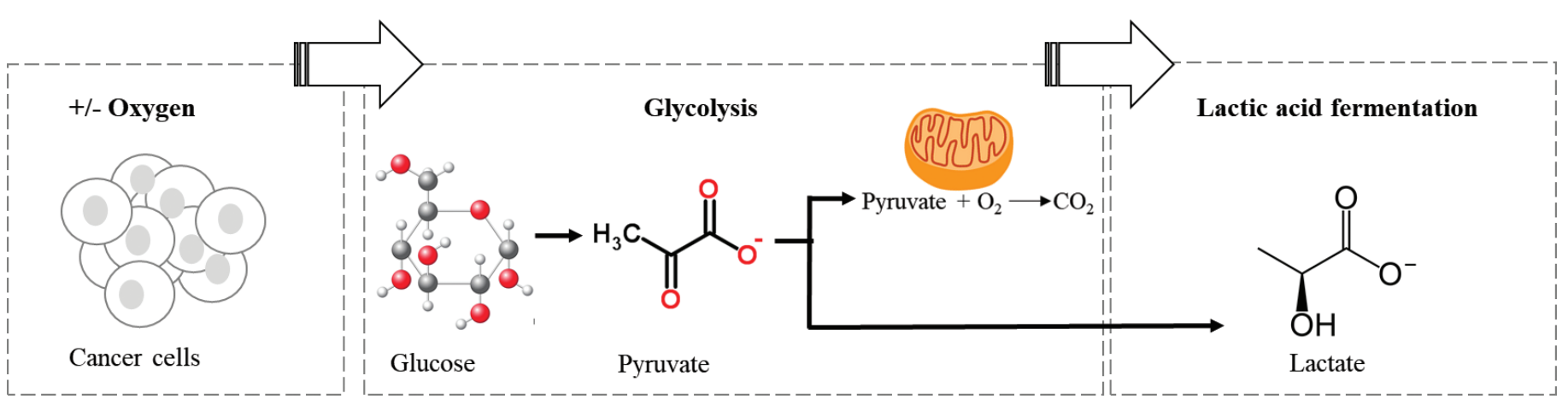

Figure 5. Schematics of aerobic glycolysis - "Warburg effect." To enable rapid proliferation, cancer cells favor high levels of glucose uptake and lactate production.

Table 2. List of CHM that inhibits cancer metabolic expression-Warburg effect.

\begin{tabular}{|c|c|c|c|c|c|}
\hline Compound & CHM & Type of Cancer & Metabolite regulation & Mechanism & Reference \\
\hline Berberine & Berberis species & Breast & Mitochondrial OXPHOS & $\begin{array}{l}\text { Regulate ACC and ACL pathway; } \\
\text { Inhibit phosphorylation of PKM2 } \\
\& \text { PFKP }\end{array}$ & Tan et al., 2014 \\
\hline Ginsenoside 20(S)-Rg3 & Panax ginseng & Ovarian & Glycolysis & Targets the STAT3/HK2 pathway & Li et al., 2015 \\
\hline \multirow[t]{4}{*}{ Apigenin } & \multirow{4}{*}{$\begin{array}{l}\text { A. graveolensvar. } \\
\text { dulce }\end{array}$} & Breast & \multirow[t]{4}{*}{ HIF- $1 \alpha$ inhibitor } & \multirow{4}{*}{$\begin{array}{l}\text { Downregulating VEGF inactivated } \\
\text { the PI3K/Akt pathway }\end{array}$} & Semenza, 2009 \\
\hline & & Ovarian & & & Choi and Kim, 2009 \\
\hline & & Prostate & & & Li et al., 2009 \\
\hline & & Lung & & & Shukla and Gupta, 2006 \\
\hline \multirow[t]{3}{*}{ Chrysin } & \multirow{3}{*}{$\begin{array}{l}\text { Oroxylum indicum } \\
\text { (L.) Vent }\end{array}$} & Prostate & \multirow{3}{*}{$\begin{array}{l}\text { Decreased HIF- } \\
1 \alpha \text { expression }\end{array}$} & \multirow[t]{3}{*}{ Apoptosis } & Samarghandian et al., 2011 \\
\hline & & Thyroid & & & Phan et al., 2011 \\
\hline & & Leukemia & & & Khoo et al., 2010 \\
\hline Shikonin & L. erythrorhizon & Leukemia & $\begin{array}{l}\text { ROS deregulation and } \\
\text { OXPHOS uncoupling }\end{array}$ & Apoptosis & Wiench et al., 2012 \\
\hline Wogonin & $\begin{array}{l}\text { S. baicalensis (Huang } \\
\text { qin) }\end{array}$ & Colon & Glucose uptake & $\begin{array}{l}\text { Inhibits PI3K/Akt signaling } \\
\text { pathway }\end{array}$ & Wang et al., 2014 \\
\hline
\end{tabular}

tomography, positron emission tomography scan (Sotgia et al., 2011).

Metabolic adaptation of tumor cells is regulated by a number of oncogenes and tumor suppressors including Myc (Lewis et al., 1997), hypoxia-inducible factor, HIF-1 $\alpha$ (Kim et al., 2006), $\mathrm{p}$ 53 (Bensinger and Christofk, 2012), and PI3K/Akt/mTOR signaling pathway (Elstrom et al., 2014). Interrupting any of the above could lead to metabolism blockade followed by cell death.

The distinct phenomena of energy production in cancer cell via aerobic glycolysis open the door to target this metabolism and its related critical enzymes such as glucose transporter GLUT1, HK, PFKFB3, mTORC1, and OXPHOS to be exploited as targets for cancer therapy. By controlling/preventing aerobic glycolysis, cancer cells can undergo starvation, and the inhibition of proliferation can be reached. Subsequently, cancer progression can be prevented. As such, the role of CHM in the development of glycolysis-based therapeutic interventions for cancer is focused in this session.

Apigenin, a plant flavonoid compound isolated from Apium graveolensvar. Dulce, acts as a HIF-1 $\alpha$ inhibitor (Semenza, 2009). This active compound showed to inhibit proliferation and to induce apoptosis in various cancers including breast (Choi and Kim, 2009), ovarian (Li et al., 2009), prostate (Shukla and Gupta, 2006), and lung(Lu et al., 2010). Apigenin was reported to inactivate PI3K/ Akt pathway in prostate cancer cells (Shukla and Gupta, 2007) and reduce HIF- $\alpha$ stability via PI3K/Akt/GSK-3 $\beta$ pathway (Mirzoeva et al., 2008). Apart from this, Chrysin (Fu et al., 2004), EGCG (Tachibana, 2009), and curcumin (Bae et al., 2006) are among other reported CHM-derived pure compounds that could control aerobic glycolysis by inhibiting HIF-1 $\alpha$ expression.

Expression of c-Myc oncogene is upregulated in the majority of human cancers including breast, colon, bladder, and prostate cancers (Dang et al., 2009). Overexpression of c-Myc is also linked to increase in many glucose metabolism enzyme genes, such as GLUT1, HK2 (Kim et al., 2007), phosphofructokinase, enolase 1, lactate dehydrogenase A, mitochondrial ROS, and pyruvate dehydrogenase kinase, thus stimulating the Warburg effect (Lewis et al., 1997; Shim et al., 1997). Table 2 shows the various CHMs in targeting the Warburg effect.

\section{CHINESE HERBAL MEDICINES UNDER CLINICAL TRIAL}

CHM has become an important and growing part of public healthcare around the world. Initially, its importance was overlooked due to the lack of scientific evidence to evaluate safety and efficacy. In this review, we have highlighted the mechanism 
Table 3. Completed clinical trials of CHM in cancer.

\begin{tabular}{|c|c|c|c|c|c|}
\hline & Title & Study results & Conditions & Interventions & Locations \\
\hline 1 & $\begin{array}{l}\text { Compound Herbal Formula (TPE-1) for Leukopenia } \\
\text { and Cancer-related Fatigue in breast Cancer Patients } \\
\text { with Radiotherapy }\end{array}$ & No results available & $\begin{array}{l}\cdot \text { Breast cancer } \\
\text { - Radiotherapy } \\
\text { - Chinese herbal medicine }\end{array}$ & - Drug: CHM decoction & Taiwan \\
\hline 2 & $\begin{array}{l}\text { Clinical Trial on Palliative Cancer Patients with } \\
\text { Constipation }\end{array}$ & No results available & - Constipation & $\begin{array}{l}\text { - Drug: CHM } \\
\text { • Drug: Placebo }\end{array}$ & Hong Kong \\
\hline 3 & $\begin{array}{l}\text { Safety and Pharmacokinetics of Jin Fu Kang in Comb } \\
\text { w/Docetaxel for Patients w/Non-Small Cell Lung } \\
\text { Cancer }\end{array}$ & No results available & - Non-small cell lung cancer & $\begin{array}{l}\text { - Drug: Docetaxel } \\
\text { • Drug: Jin Fu Kang }\end{array}$ & United States \\
\hline 4 & $\begin{array}{l}\text { A Phase II Multicenter, Randomized, Placebo } \\
\text { Controlled, Double Blinded Clinical Study of KD018 } \\
\text { as a Modulator of Irinotecan chemo-therapy in } \\
\text { Patients with Metastatic Colorectal Cancer }\end{array}$ & Results available & - Colorectal neoplasms & $\begin{array}{l}\text { - Drug: KD018 } \\
\text { • Drug: Irinotecan } \\
\text { • Drug: Placebo }\end{array}$ & United States \\
\hline 5 & $\begin{array}{l}\text { Sho-Saiko-To Following Removal of Liver Cancer by } \\
\text { Embolization in Treating Patients with Liver Cancer } \\
\text { That Cannot Be Surgically Removed }\end{array}$ & No results available & - Liver cancer & $\begin{array}{l}\text { - Dietary Supplement: Sho- } \\
\text { saiko-to }\end{array}$ & United States \\
\hline 6 & $\begin{array}{l}\text { Life Quality and Mental State in Patients with Breast } \\
\text { Cancer }\end{array}$ & No results available & - Breast cancer & $\begin{array}{l}\text { - Other: Individualized } \\
\text { complementary } \\
\text { - medicine treatment } \\
\text { - Other: Individualized usual care }\end{array}$ & Italy \\
\hline 7 & $\begin{array}{l}\text { Cross Sectional Study of Constipation in Advanced } \\
\text { Cancer Patients }\end{array}$ & No results available & $\begin{array}{l}\text { - Palliative care } \\
\text { - Constipation } \\
\text { - Traditional Chinese medicine }\end{array}$ & & Hong Kong \\
\hline 8 & $\begin{array}{l}\text { Combination Chemotherapy After Surgery with or } \\
\text { Without Chinese Herbal Therapy to Treat Symptoms } \\
\text { in Women with Breast Cancer }\end{array}$ & No results available & $\begin{array}{l}\text { - Breast cancer } \\
\text { - Drug/Agent Toxicity by } \\
\text { Tissue/Organ }\end{array}$ & $\begin{array}{l}\text { - Dietary Supplement: Chinese } \\
\text { herbs } \\
\text { - Drug: cyclophosphamide } \\
\text { - Drug: doxorubicin hydrochloride } \\
\text { - Procedure: adjuvant therapy }\end{array}$ & United States \\
\hline 9 & $\begin{array}{l}\text { Study of TLBZT Based Herbal Therapy Plus } \\
\text { Chemotherapy for Metastatic Colorectal Cancer }\end{array}$ & No results available & - Metastatic colorectal cancer & $\begin{array}{l}\text { - Drug: Chemotherapy } \\
\text { • Drug: Herbal therapy }\end{array}$ & China \\
\hline 10 & $\begin{array}{l}\text { Chinese Herbal Medicine for Immune Reconstitution } \\
\text { Following HSCT in Acute Leukemia Patients }\end{array}$ & No results available & - Acute leukemia & $\begin{array}{l}\text { - Dietary Supplement: Sheng- } \\
\text { Yu-Tang }\end{array}$ & Taiwan \\
\hline 11 & $\begin{array}{l}\text { Herbal Therapy in Treating Women with Metastatic } \\
\text { Breast Cancer }\end{array}$ & No results available & - Breast cancer & $\begin{array}{l}\text { - Drug: herba S. barbata } \\
\text { - Other: herba S. Barbatae (HSB) }\end{array}$ & United States \\
\hline 12 & $\begin{array}{l}\text { Treatment of Anal HSIL Through Use of a Chinese } \\
\text { Herbal Topical Cream }\end{array}$ & Results available & - Anus neoplasms & $\begin{array}{l}\cdot \text { Drug: AIJP } \\
\text { • Drug: Placebo }\end{array}$ & United States \\
\hline 13 & $\begin{array}{l}\text { Traditional Chinese Medicine in the Supportive } \\
\text { Management of Anaemic and Cytopenic (Leukopenia, } \\
\text { hrombocytopenia) Haematological Disorders }\end{array}$ & No results available & $\begin{array}{l}\text { - Myelodysplastic Syndrome } \\
\text { (MDS) } \\
\text { - Aplastic anaemia (AA) } \\
\text { - Myelofibrosis (MF) } \\
\text { - Thalassemia intermedia }\end{array}$ & $\begin{array}{l}\text { - Drug: Chinese herbal concoction } \\
\text { twice a day for } 6 \text { months }\end{array}$ & Singapore \\
\hline
\end{tabular}

ClinicalTrials.gov Search Results 06/18/2019.

behind the potential use of CHM in inhibiting cancer development. However, to further widen their acceptance globally and to promote herbal medicines into conventional medical practices, clinical trials of these medicinal plants are encouraged. As such, Table 3 shows the completed clinical trials of CHM in breast, lung, anal, leukemia, liver, and colorectal cancers (http://clinicaltrials. gov/). Among the listed 13 completed clinical studies, only two studies were shown to have available results. A phase II study was carried out from 2008 to 2018 to investigate the mechanism and efficacy of CHM as an adjunct to chemotherapy in the treatment of patients with metastatic colorectal cancer. In the CHM, KD018 is an oral form of a spray-dried aqueous extract composed of Huang Qin Tang herbal mixture (Glycyrrhiza uralensis Fisch, Paeonia lactiflora Pall, S. baicalensis Georgi, and Ziziphus jujube Mill), which have been used against gastrointestinal (GI) infectious symptoms including diarrhea and nausea/vomiting. A therapeutic use of KD018 was tested for its potential activity in reducing chemotherapy-induced toxicity, especially diarrhea. The CHM was shown to decrease GI toxicity induced by the chemotherapeutic drug CPT-11 (irinotecan) and increase the antitumor activity of irinotecan while decreasing weight loss caused by irinotecan (Lam et al., 2010). Next, phase II study on anal high-grade squamous 
intraepithelial lesions (HSIL) through the use of a Chinese herbal topical cream by the University of California was carried out from 2008 to 2012. This CHM that consists of Arnebia Indigo Jade Pearl (AIJP) was applied as a noninvasive topical cream for the treatment of precancerous anal lesions caused by human papillomavirus to prevent their progression to anal cancer.

With the growing scientific evidence on the safety and efficacy of CHM in clinical trial, CHM-based drugs can be confidently used to treat cancer. With more clinical trials on CHM conducted, this may allow the integration of CHM into the current conventional healthcare systems.

\section{Perspectives}

CHM has the potential to develop anticancer drug against the deadliest disease, cancer. CHM's ability to significantly target all the hallmarks of cancer proves the millennia-old Chinese medicine's efficacy to work against various cancers. While in the beginning, it was only prescribed by $\mathrm{CHM}$ practitioner without any standard protocol to prepare and was not well documented, thus missing of scientific evidence that made it not well received by conventional medicine. Over the decades, tremendous efforts and intellectual contributions have been given to reveal the mode of action and mechanism behind its effectiveness. For example, with modern scientific techniques including isolation, extraction, active compound detection, biological assays, RNA, and DNA extractions, in vitro and in vivo analysis made it possible for a better understanding of CHM and its role to treat this malignancy. However, a number of limitations and challenges have existed, which reduces the progress of studies on the use of CHM in cancer treatment. Most importantly, there was a great controversy about CHM use of complex/whole mixture in contrast to isolate bioactive single compounds. In mixture, hundreds of compounds might work together synergistically to enhance therapeutic effect, and also, this could enable the treatment with less or no side effects. For the same scenario, there are chances to have unstable and unreactive compounds present in the composite mixture. By isolating active compounds, the mechanism of action for treatment could be clearly revealed and understood. Next, mostly, CHM knowledge and preparation techniques are inherited, and based on the reports provided by ancient physicians, many of which lack the standardized procedure and criteria. This definitely sets a drawback for CHM to be well-accepted and confidently used as a treatment regime. It is necessary to introduce a holistic strategy and evidence-based approaches to further study CHM.

\section{CONFLICT OF INTEREST}

Authors declared that there are no conflicts of interest.

\section{FUNDING}

None.

\section{REFERENCES}

Arbiser JL, Klauber N, Rohan R, Van Leeuwen R, Huang M-T, Fisher C, Flynn E, Byers HR. Curcumin is an in vivo inhibitor of angiogenesis. Mol Med, 1998; 4:376-83.

Bae MK, Kim SH, Jeong JW, Lee YM, Kim HS, Kim SR, Yun I, Bae SK, Kim KW. Curcumin inhibits hypoxia-induced angiogenesis via down-regulation of HIF-1. Oncol Rep, 2006; 15(6):1557-62.

Bartek J, Bartkova J, Lukas J. The retinoblastoma protein pathway in cell cycle control and cancer. J Exp Cell Res, 1997; 237(1):1-6.
Bensinger SJ, Christofk HR. New aspects of the Warburg effect in cancer cell biology. Semin Cell Dev Biol, 2012; 23(4):352-61.

Chai XS, Zhang XX, Wu WY. Xiaoji Decoction inhibited cell proliferation and induced apoptosis through Akt signaling pathway in human lung cancer A549 cells. Chin J Integr Med, 2014; 20:701-5.

Chan K, Lee H. The way forward for Chinese medicine. Taylor \& Francis, London, NY, 2002.

Chao JC, Chu CC. Effects of Ginkgo biloba extract on cell proliferation and cytotoxicity in human hepatocellular carcinoma cells. World J Gastroenterol, 2004; 10:37-41.

Chau BN, Wang JY. Coordinated regulation of life and death by RB. Nat Rev Cancer, 2003; 3(2):130-8.

Chen X, Wong YK, Lim TK, Lim WH, Lin Q, Wang J, Hua Z. Artesunate activates the intrinsic apoptosis of HCT116 cells through the suppression of fatty acid synthesis and the NF- $\mathrm{kB}$ pathway. Molecules, 2017; 22(8):1272.

Cho WCS, Leung KN. In vitro and in vivo anti-tumor effects of Astragalus membranaceus. Cancer Lett, 2007; 252:43-54.

Choi EJ, Kim GH. Apigenin induces apoptosis through a mitochondria/caspase-pathway in human breast cancer MDA-MB-453 cells. J Clin Biochem Nutr, 2009; 44(3):260-5.

Cobrinik D. Pocket proteins and cell cycle control. Oncogene, 2005; 24(17):2796-809.

Dang CV, Le A, Gao P. MYC-induced cancer cell energy metabolism and therapeutic opportunities. Clin Cancer Res, 2009; 15:6479-83.

Dang XY, Dong L, Shi HT, Zou BC. Effects of serum containing Chinese medicine Sanpi Pingwei (散癖平胃) formula on proliferation and apoptosis of human SGC-7901 cells. Chin J Integr Med, 2013; 19(2):119-26.

Daniel NN, Korsmeyer SJ. Cell death critical control points. Cell, 2004; 116:205-19.

Dasgupta P, Padmanabhan J, Chellappan $\mathrm{S}$. Rb function in the apoptosis and senescence of non-neuronal and neuronal cells: role in oncogenesis. Curr Mol Med, 2006; 6 (7):719-29.

DeBerardinis RJ, Lum JJ, Hatzivassiliou G, Thompson CB. The biology of cancer: metabolic reprogramming fuels cell growth and proliferation. Cell Metab, 2008; 7:11-20.

Deng W, Sui H, Wang Q, He N, Duan C, Han L, Li Q, Lu M, Ly S. A Chinese herbal formula, Yi-Qi-Fu-Sheng, inhibits migration/invasion of colorectal cancer by down-regulating MMP-2/9 via inhibiting the activation of ERK/MAPK signaling pathways. BMC Complement Altern Med, 2013; 13:65.

Dong LH, Wen JK, Miao SB, Jia Z, Hu HJ, Sun RH, Wu Y, Han M. Baicalin inhibits PDGF-BB-stimulated vascular smooth muscle cell proliferation through suppressing PDGFR $\beta$-ERK signaling and increase in p27 accumulation and prevents injury-induced neointimal hyperplasia. Cell Res, 2010; 20(11):1252-62.

Efferth T, Davey M, Olbrich A, Rucker G, Gebhart E, Davey R. Activity of drugs from Chinese herb medicine toward sensitive and MDR1or MRP1-overexpressing multidrug-resistant human CCRF-CEM leukemia cells. Blood Cells Mol Dis, 2002; 28:160-8.

Elstrom RL, Bauer DE, Buzzai M, Karnauskas R, Harris MH, Plas DR, Zhuang H, Cinalli RM, Alavi A, Rudin CM, Thompson CB. Akt stimulates aerobic glycolysis in cancer cells. Cancer Res, 2004; 64(11):3892-9.

Fan W, Sun L, Zhou JQ, Zhang C, Qin S, Tang Y, Liu Y, Lin SS, Yuan ST. Marsdenia tenacissima extract induces G0/G1 cell cycle arrest in human esophageal carcinoma cells by inhibiting mitogen-activated protein kinase (MAPK) signaling pathway. Chin J Nat Med, 2015; 13(6):428-37.

Fang EF, Zhang CZ, Wong JH, Shen JY, Li CH, and Ng TB. The MAP30 protein from bitter gourd (Momordica charantia) seeds promotes apoptosis in liver cancer cells in vitro and in vivo. Cancer Lett, 2012; 324:66-74.

Fox JL. Obama catapults patient-empowered precision medicine. Nat Biotechnol, 2015; 33(4):325.

Fromenti S, Demaria S. Systemic effects of local radiotherapy. Lancet Oncol, 2009; 10:718-26; doi:10.1016/S1470-2045(09)70082-8. 
Fu Y, Hsieh TC, Guo J, Kunicki J, Lee MY, Darznkiewicz $\mathrm{Z}$, Wu JM. Licochalcone-A, a novel flavonoid isolated from licorice root (Glycyrrhiza glabra), causes G2 and late-G1 arrests in androgenindependent PC-3 prostate cancer cells. Biochem Biophys Res Commun, 2004; 322(1):263-70.

Gali-Muhtasib H, Diab-Assaf M, Boltze C, Al-Hmaira J, Hartig R, Roessner A, Schneider-Stock R. Thymoquinone extracted from black seed triggers apoptotic cell death in human colorectal cancer cells via a p53-dependent mechanism. Int J Oncol, 2004; 25(4):857-66.

Galluzzi L, Vitale I, Aaronson SA, Abrams JM, Adam D, Agostinis P, Alnemri ES, Altucci L, Amelio I, Andrews DW, AnnicchiaricoPetruzzelli M, Antonov AV, Arama E, Baehrecke EH, Barlev NA, Bazan NG, Bernassola F, Bertrand MJM, Bianchi K, Blagosklonny MV, Blomgren K, Borner C, Boya P, Brenner C, Campanella M, Candi E, Carmona-Gutierrez D, Cecconi F, Chan FK, Chandel NS, Cheng EH, Chipuk JE, Cidlowski JA, Ciechanover A, Cohen GM, Conrad M, Cubillos-Ruiz JR, Czabotar PE, D'Angiolella V, Dawson TM, Dawson VL, De Laurenzi V, De Maria R, Debatin KM, DeBerardinis RJ, Deshmukh M, Di Daniele N, Di Virgilio F, Dixit VM, Dixon SJ, Duckett CS, Dynlacht BD, El-Deiry WS, Elrod JW, Fimia GM, Fulda S, García-Sáez AJ, Garg AD, Garrido C, Gavathiotis E, Golstein P, Gottlieb E, Green DR, Greene LA, Gronemeyer H, Gross A, Hajnoczky G, Hardwick JM, Harris IS, Hengartner MO, Hetz C, Ichijo H, Jäättelä M, Joseph B, Jost PJ, Juin PP, Kaiser WJ, Karin M, Kaufmann T, Kepp O, Kimchi A, Kitsis RN, Klionsky DJ, Knight RA, Kumar S, Lee SW, Lemasters JJ, Levine B, Linkermann A, Lipton SA, Lockshin RA, López-Otín C, Lowe SW, Luedde T, Lugli E, MacFarlane M, Madeo F, Malewicz M, Malorni W, Manic G, Marine JC, Martin SJ, Martinou JC, Medema JP, Mehlen P, Meier P, Melino S, Miao EA, Molkentin JD, Moll UM, Muñoz-Pinedo C, Nagata S, Nuñez G, Oberst A, Oren M, Overholtzer M, Pagano M, Panaretakis T, Pasparakis M, Penninger JM, Pereira DM, Pervaiz S, Peter ME, Piacentini M, Pinton P, Prehn JHM, Puthalakath H, Rabinovich GA, Rehm M, Rizzuto R, Rodrigues CMP, Rubinsztein DC, Rudel T, Ryan KM, Sayan E, Scorrano L, Shao F, Shi Y, Silke J, Simon HU, Sistigu A, Stockwell BR, Strasser A, Szabadkai G, Tait SWG, Tang D, Tavernarakis N, Thorburn A, Tsujimoto Y, Turk B, Vanden Berghe T, Vandenabeele P, Vander Heiden MG, Villunger A, Virgin HW, Vousden KH, Vucic D, Wagner EF, Walczak H, Wallach D, Wang Y, Wells JA, Wood W, Yuan J, Zakeri Z, Zhivotovsky B, Zitvogel L, Melino G, Kroemer G. Molecular mechanisms of cell death: recommendations of the nomenclature committee on cell death 2018. Cell Death Differ, 2018; 25:486-541.

Gao J, Morgan WA, Sanchez-Medina A, Corcoran O. The ethanol extract of $S$. baicalensis and the active compounds induce cell cycle arrest and apoptosis including upregulation of $\mathrm{p} 53$ and Bax in human lung cancer cells. Toxicol Appl Pharmacol, 2011; 254(3):221-8.

Haddad PS, Azar G A, Groom S, Boivin M. Natural health products, modulation of immune function and prevention of chronic diseases. Evid Based Complement Alternat Med, 2005; eCAM. 2(4):51320 .

Haghshenas V, Fakhari S, Mirzaie S, Rahmani M, Farhadifar F, Pirzadeh S, Jalili A. Glycyrrhetinic acid inhibits cell growth and induces apoptosis in ovarian cancer A2780 Cells. Adv Pharm Bull, 2014; 4(Suppl 1):437-41.

Hahm ER, Singh SV. Honokiol causes G-G1 phase cell cycle arrest in human prostate cancer cells in association with suppression of retinoblastoma protein level/phosphorylation and inhibition of E2F1 transcriptional activity. Mol Cancer Ther, 2007; 6(10):2686-95.

Han W, Li L, Qiu S, Lu Q, Pan Q, Gu Y, Luo J, Hu X. Shikonin circumvents cancer drug resistance by induction of a necroptotic death. Mol Cancer Ther, 2007; 6(5):1641-9.

Han W, Xie J, Li L, Liu Z, Hu X. Necrostatin-1 reverts shikonininduced necroptosis to apoptosis. Apoptosis, 2009; 14(5):674-86.

Hanahan D, Folkman J. Patterns and emerging mechanisms of the angiogenic switch during tumorigenesis. Cell, 1996; 86:353-64.

Hanahan D, Weinberg RA. Hallmarks of cancer: the next generation. Cell, 2011; 144:646-74; doi:10.1016/j.cell.2011.02.013.
Hofseth LJ, Wargovich MJ. Inflammation, cancer, and targets of ginseng. J Nutr, 2007; 137(Suppl 1):183S-5S.

Hsu CM, Tsai Y, Wan L, Tsai FJ. Bufalin induces G2/M phase arrest and triggers autophagy via the TNF, JNK, BECN-1 and ATG8 pathway in human hepatoma cells. Int J Oncol, 2013; 43(1):338-48.

Huang Y, Song H, Hu H, Cui L, You C, Huang L. Trichosanthin inhibits DNA methyltransferase and restores methylation-silenced gene expression in human cervical cancer cells. Mol Med Rep, 2012; 6(4):872-8.

Huyan T, Li Q, Yang H, Jin ML, Zhang MJ, Ye LJ, Li J, Huang QS, Yin DC. Protective effect of polysaccharides on simulated microgravityinduced functional inhibition of human NK cells. Carbohydr Polym, 2014; 101:819-27.

Jia Y, Guan Q, Guo Y, Du C. Reduction of inflammatory hyperplasia in the intestine in colon cancer-prone mice by water-extract of Cistanche deserticola. Phytotherapy Res, 2012; 26(6):812-9.

Jian W, Yuan Z, Huang X, Chen Q, Zheng JH, Li Y. Analysis on urine metabolomics of coronary heart disease patients with the heart blood stasis syndrome. J Tradit Chin Med, 2010; 51(8):729-32.

Jiang WG, Ye L, Ji K, Frewer N, Ji J, Mason MD. Inhibitory effects of Yangzheng Xiaoji on angiogenesis and the role of the focal adhesion kinase pathway. Int J Oncol, 2012; 41(5):1635-42.

Jung Y, Jerng U, Lee S. A systematic review of anticancer effects of Radix Astragali. Chin J Integr Med, 2016; 22(3):225-36; doi:10.1007/ s11655-015-2324-x.

Kang N, Zhang J, Qiu F, Tashiro S, Onodera S, Ikejima T. Inhibition of EGFR signaling augments oridonin-induced apoptosis in human laryngeal cancer cells via enhancing oxidative stress coincident with activation of both the intrinsic and extrinsic apoptotic pathways. Cancer Lett, 2010; 294(2):147-58.

Khoo BY, Chua SL, Balaram P. Apoptotic effects of chrysin in human cancer cell lines. Int J Mol Sci, 2010; 11(5):2188-99.

Kim JW, Gao P, Liu YC, Semenza GL, Dang CV. Hypoxiainducible factor 1 and dysregulated c-Myc cooperatively induce vascular endothelial growth factor and metabolic switches hexokinase 2 and pyruvate dehydrogenase kinase 1. Mol Cell Biol, 2007; 27:7381-93.

Kim JW, Tchernyshyov I, Semenza GL, Dang CV. HIF-1mediated expression of pyruvate dehydrogenase kinase: a metabolic switch required for cellular adaptation to hypoxia. Cell Metab, 2006; 3(3):177-85.

Kim KS, Rhee KH, Yoon JH, Lee JG, Lee JH, Yoo JB. Ginkgo biloba extract (EGb 761) induces apoptosis by the activation of caspase-3 in oral cavity cancer cells. Oral Oncol, 2005; 41:383-9.

Kitagishi Y, Kobayashi M, Matsuda S. Protection against cancer with medicinal herbs via activation of tumor suppressor. J Oncol, 2012; 2012:236530

Kroemer G, Galluzzi L, Vandenabeele P, Abrams J, Alnemri ES, Baehrecke EH, Blagosklonny MV, El-Deiry WS, Golstein P, Green DR, Hengartner M, Knight RA, Kumar S, Lipton SA, Malorni W, Nuñez G, Peter ME, Tschopp J, Yuan J, Piacentini M, Zhivotovsky B, Melino G; Nomenclature Committee on Cell Death 2009. Classification of cell death: recommendations of the Nomenclature Committee on Cell Death 2009. Cell Death Differ, 2008; 16(1):3-11.

Kwon H, Park HY, Kim JY, Jeong IY, Lee MK, Seo KI. Apoptotic action of ursolic acid isolated from Corni fructus in RC-58T/h/ SA\#4 primary human prostate cancer cells. Bioorg Med Chem Lett, 2010; 20(22):6435-8

Lam HK, Li K, Chik KW, Yang M, Liu VC, Li CK, Fok TF, Ng PC, Shing MM, Chuen CK, Yuen PM. Arsenic trioxide mediates intrinsic and extrinsic pathways of apoptosis and cell cycle arrest in acute megakaryocytic leukemia. Int J Oncol, 2005; 27:537-45.

Lam W, Bussom S, Guan F, Jiang Z, Zhang W, Gullen EA, Liu SH, Cheng YC. The four-herb Chinese medicine PHY906 reduces chemotherapy-induced gastrointestinal toxicity. Sci Transl Med, 2010; 2(45):45ra59; doi:10.1126/scitranslmed.3001270

Lee SJ, Kim HM, Cho YH, Park K, Kim EJ, Jung KH, Kim $\mathrm{CH}$, Kim WJ, Moon SK. Aqueous extract of Magnolia officinalis mediates 
proliferative capacity, p21WAF1 expression and TNF-alpha-induced NFkappaB activity in human urinary bladder cancer 5637 cells; involvement of p38 MAP kinase. Oncol Rep, 2007; 18(3):729-36.

Lee SJ, Park K, Ha SD, Kim WJ, Moon SK. Gleditsia sinensis thorn extract inhibits human colon cancer cells: the role of ERK1/2, G2/M-phase cell cycle arrest and p53 expression. Phytothe Res, 2010; 24(12):1870-6

Lee SJ, Park SS, Kim WJ, Moon SK. Gleditsia sinensis thorn extract inhibits proliferation and TNF- $\alpha$-induced MMP-9 expression in vascular smooth muscle cells. Am J Chin Med, 2012; 40(2):373-86.

Lewis BC, Shim H, Li Q, Wu CS, Lee LA, Maity A, Dang CV. Identification of putative c-Myc-responsive genes: characterization of rcl, a novel growth-related gene. Mol Cell, 1997; 17:4967.

Li B, Zhao J, Wang CZ, Searle J, He TC, Yuan CS, Du W. Ginsenoside Rh2 induces apoptosis and paraptosis-like cell death in colorectal cancer cells through activation of p53. Cancer Lett, 2011; 301(2):185-92.

Li J, Liu T, Zhao L, Chen W, Hou H, Ye Z, Li X. Ginsenoside 20(S)-Rg3 inhibits the Warburg effect through STAT3 pathways in ovarian cancer cells. Int J Oncol, 2015; 46(2):775-81.

Li S, Zhang ZQ, Wu LJ, Zhang XG, Li YD, Wang YY. Understanding ZHENG in traditional Chinese medicine in the context of neuro-endocrine-immune network. IET Syst Biol, 2007; 1(1):51-60.

Li XT, Zhao J. An approach to the nature of qi in TCM-Qi and bioenergy, recent advances in theories and practice of Chinese medicine, Prof. In: Kuang H (ed.). ISBN: 978-953-307-903-5, InTech, Luton, UK, 2012. Available from: http://www.intechopen.com/books/recent-advancesin-theories-and-practice-of-chinesemedicine/an-approach-to-the-nature-ofqi-in-tcm-qi-and-bioenergy

Li ZD, Hu XW, Wang YT, Fang J. Apigenin inhibits proliferation of ovarian cancer A2780 cells through Id1. FEBS Lett, 2009; 583(12):19992003.

Liebermann DA, Hoffman B, Vesely D. p53 induced growth arrest versus apoptosis and its modulation by survival cytokines. Cell Cycle, 2007; 6(2):166-70.

Lipinski MM, Jacks T. The retinoblastoma gene family in differentiation and development. Oncogene, 1999; 18(55):7873-82.

Liu H, Zang C, Emde A, Planas-Silva MD, Rosche M, Kuhnl A, Schulz CO, Elstner E, Possinger K, Eucker J. Anti-tumor effect of honokiol alone and in combination with other anti-cancer agents in breast cancer. Eur J Pharmacol, 2008; 591(1-3):43-51.

Liu J, Wang S, Zhang Y, Fan HT, Lin HS. Traditional Chinese medicine and cancer: history, present situation and development. Thorac Cancer, 2015; 6(5):561-69.

Liu W, Li SY, Huang XE, Cui JJ, Zhao T, Zhang H. Inhibition of tumor growth in vitro by a combination of extracts from Rosa roxburghii tratt and Fagopyrum cymosum. Asian Pac J Cancer Prev, 2012; 13:2409-14.

Lu C, Xiao C, Chen G, Jiang M, Zha Q, Yan X, Kong W, Lu A. Cold and heat pattern of rheumatoid arthritis in traditional Chinese medicine: distinct molecular signatures identified by microarray expression profiles in CD4-positive T cell. Rheumatol Int, 2010; 32(1):61-8.

Lu HF, Chie YJ, Yang MS, Lee CS, Fu JJ, Yang JS, Tan TW, Wu SH, Ma YS, Ip SW, Chung JG. Apigenin induces caspase-dependent apoptosis in human lung cancer A549 cells through Bax- and Bcl-2triggered mitochondrial pathway. Int J Oncol, 2010; 36(6):1477-84.

$\mathrm{Lu}$ JM, Yao Q, Chen C. Ginseng compounds: an update on their molecular mechanisms and medical applications. Curr Vasc Pharmacol, 2009; 7(3):293-302.

Lu Y, Li CS, Dong Q. Chinese herb related molecules of cancercell-apoptosis: a minireview of progress between Kanglaite injection and related genes. J Exp Clin Cancer Res, 2008; 27(1):31.

Lu YH, Hao HP, Wang GJ, Chen XH, Zhu XX, Xiang BR. Metabolomics approach to the biochemical differentiation of traditional Chinese medicine syndrome types of hypertension. Chinese J Clin Pharmacol Ther, 2007; 12(10):1144-50.

Ma YH, Cheng WZ, Gong F, Ma AL, Yu QW, Zhang JY, Hu CY, Chen XH, Zhang DQ. Active Chinese mistletoe lectin-55 enhances colon cancer surveillance through regulating innate and adaptive immune responses. World J Gastroenterol, 2008; 14:5274-81.

Ma L, Li W. Emodin inhibits LOVO colorectal cancer cell proliferation via the regulation of the $\mathrm{Bcl}-2 / \mathrm{Bax}$ ratio and cytochrome $\mathrm{c}$. Exp Ther Med, 2014; 8:1225-8.

Martin F, Gerd M. Cell cycle transcription control: DREAM/ MuvB and RB-E2F complexes. Crit Rev Biochem Mol Biol, 2017; 52:6, 638-62.

Meir VH, Nout RA, Welters MJP, Loof NM, de Kam ML, van Ham JJ, Samuels S, Kenter GG, Cohen AF, Melief CJ, Burggraaf J, van Poelgeest MI, van der Burg SH. Impact of (chemo) radiotherapy on immune cell composition and function in cervical cancer patients. Oncoimmunology, 2017; 6:e1267095; doi:10.1080/2162402X.2016.1267095.

Mirzoeva S, Kim ND, Chiu K, Franzen CA, Bergan RC, Pelling JC. Inhibition of HIF-1 alpha and VEGF expression by the chemopreventive bioflavonoid apigenin is accompanied by Akt inhibition in human prostate carcinoma PC3-M cells. Mol Carcinog, 2008; 47(9):686-700.

Mishra BB, Tiwari VK. Natural products: an evolving role in future drug discovery. Eur J Med Chem, 2011; 46:4769-807.

Monograph Astragalus membranaceus. Altern Med Rev, 2003;8:72-77.

Moran A, Carothers AM, Weyant MJ, Redston M, Bertagnolli MM. Carnosol inhibits $\beta$-catenin tyrosine phosphorylation and prevents adenoma formation in the $\mathrm{C} 57 \mathrm{BL} / 6 \mathrm{~J} / \mathrm{Min} /+(\mathrm{Min} /+)$ Mouse. Cancer Res, 2005; 65(3):1097-104

Mousa SA, Davis PJ. Angiogenesis and anti-angiogenesis strategies in cancer. In: Mousa SA, Davis PJ (ed.). Anti-angiogenesis strategies in cancer therapies. 1st edition, Academic Press, Amsterdam, Netherlands, 2016.

Narayanan NK, Nargi D, Randolph C, Narayanan BA. Liposome encapsulation of curcumin and resveratrol in combination reduces prostate cancer incidence in PTEN knockout mice. Int J Cancer, 2009; 125(1):1-8.

Newman DJ, Cragg GM. Natural products as sources of new drugs from 1981 to 2014. J Nat Prod, 2016; 79:629-61.

Nishida N, Yano H, Nishida T, Kamura T, Kojiro M. Angiogenesis in cancer. Vasc Health Risk Manag, 2006; 2(3):213-9.

O’Neil N, Rose A. DNA repair. WormBook, 2006; 13:1-12.

Oz HS, Ebersole JL. Green tea polyphenols mediated apoptosis in intestinal epithelial cells by a FADD-dependent pathway. J Cancer Ther, 2010; 1(3):105-13.

Palit S, Kar S, Sharma G, Das PK. Hesperetin Induces Apoptosis in breast carcinoma by triggering accumulation of ROS and activation of ASK1/JNK pathway. J Cell Physiol, 2015; 230(8):1729-39.

Papadopoulos V, Kapsis A, Li H, Amri H, Hardwick M, Culty M, Kasprzyk PG, Carlson M, Moreau JP, Drieu K. Drug-induced inhibition of the peripheral-type benzodiazepine receptor expression and cell proliferation in human breast cancer cells. Anticancer Res, 2000; 20:2835-47.

Peng Q, Cai H, Sun X, Li X, Mo Z, Shi J. Alocasia cucullata exhibits strong antitumor effect in vivo by activating antitumor immunity. PLoS One, 2013; 8:e75328.

Peng Y, Fu Z, Guo C-S, Zhang YX, Di Y, Jiang B, Li QW. Effects and mechanism of Baicalin on apoptosis of cervical cancer HeLa Cells Invitro. Iran J Pharm Res, 2015; 14(1):251-61.

Pereira DM, Valentao P, Correia-da-Silva G, Teixeira N, Andrade PB. Plant secondary metabolites in cancer chemotherapy: where are we? Curr Pharm Biotechnol, 2012; 13:632-50.

Perez AT, Arun B, Tripathy D, Tagliaferri MA, Shaw HS, Kimmick GG, Cohen I, Shtivelman E, Caygill KA, Grady D, Schactman M, Shapiro CL. A phase 1B dose escalation trial of S. barbata (BZL101) for patients with metastatic breast cancer. Breast Cancer Res Treat, 2010; 120(1):111-8

Phan T, Yu XM, Kunnimalaiyaan M, Chen H. Antiproliferative effect of chrysin on anaplastic thyroid cancer. J Surg Res, 2011; 170(1):84-8.

Ritenbaugh C, Hammerschlag R, Dworkin SF, Aickin MG, Mist SD, Elder CR, Harris RE. Comparative effectiveness of traditional Chinese medicine and psychosocial care in the treatment of temporomandibular 
disorders-associated chronic facial pain. J Pain, 2012; 13(11):1075-89; doi:10.1016/j.jpain.2012.08.002.

Samarghandian S, Afshari JT, Davoodi S. Chrysin reduces proliferation and induces apoptosis in the human prostate cancer cell line pc-3. Clinics, 2011; 66(6):1073-9.

Semenza GL. HIF-1 inhibitors for cancer therapy: from gene expression to drug discovery. Curr Pharm Des, 2009; 15(33):3839-43.

Shan BE, Zeki K, Sugiura T, Yoshida Y, Yamashita U. Chinese medicinal herb, Acanthopanax gracilistylus, extract induces cell cycle arrest of human tumor cells in vitro. Jap J Cancer Res, 2000; 91(4):383-9.

Shay JW, Wright WE. Role of telomeres and telomerase in cancer. Semin Cancer Biol, 2011; 21(6):349-53.

Sherman-Baust CA, Weeraratna AT, Rangel LB, Pizer ES, Cho KR, Schwartz DR, Shock T, Morin PJ. Remodeling of the extracellular matrix through overexpression of collagen VI contributes to cisplatin resistance in ovarian cancer cells. Cancer Cell, 2003; 3(4):377-86.

Shim H, Dolde C, Lewis BC, Wu CS, Dang G, Jungmann RA, Dalla-Favera R, Dang CV. c-Myc transactivation of LDH-A: implications for tumor metabolism and growth. Proc Natl Acad Sci USA, 1997; 94:6658-63.

Shintani T, Klionsky DJ. Autophagy in health and disease: a double-edged sword. Science, 2004; 306:990-5.

Shukla S, Gupta S. Apigenin-induced cell cycle arrest is mediated by modulation of MAPK, PI3K-Akt, and loss of cyclin D1 associated retinoblastoma dephosphorylation in human prostate cancer cells. Cell Cycle, 2007; 6(9):1102-14.

Shukla S, Gupta S. Molecular targets for apigenin induced cell cycle arrest and apoptosis in prostate cancer cell xenograft. Mol Cancer Ther, 2006; 5(4):843-52.

Sotgia F, Martinez-Outschoorn UE, Pavlides S, Howell A, Pestell $\mathrm{RG}$, Lisanti MP. Understanding the Warburg effect and the prognostic value of stromal caveolin-1 as a marker of a lethal tumor microenvironment. Breast Cancer Res, 2011; 13(4):213.

Stewart BW, Wild CP. (eds.). World cancer report 2014. International agency for research on cancer (IARC), Lyon, France, p 630, 2014, ISBN 978-92-832-0429-9.

Su J, Cheng H, Zhang D, Wang M, Xie C, Hu Y, Chang HC, Li Q. Synergistic effects of 5-fluorouracil and gambogenic acid on A549 cells: activation of cell death caused by apoptotic and necroptotic mechanisms via the ROS-mitochondria pathway. Biol Pharm Bull, 2014; 37:1259-68.

Sun C, Yu Y, Wang L, Wu B, Xia L, Feng F, Ling Z, Wang $\mathrm{S}$. Additive anti-angiogenesis effect of ginsenoside $\mathrm{Rg} 3$ with low-dose metronomic temozolomide on rat glioma cells both in vivo and in vitro. $\mathrm{J}$ Exp Clin Cancer Res, 2016; 35:32.

Sun L, Wang X. Effects of allicin on both telomerase activity and apoptosis in gastric cancer SGC-7901 cells. World J Gastroenterol, 2003; 9:1930-4.

Tachibana H. Molecular basis for cancer chemoprevention by green tea polyphenol EGCG. Forum Nutr, 2009; 61:156-69.

Tan W, Li N, Tan R, Zhong Z, Suo Z, Yang X, Wang Y, Hu X. Berberine interfered with breast cancer cells metabolism, balancing energy homeostasis. AntiCancer Agents Med Chem, 2014; 15(1):66-78.

Tang YC, Zhang Y, Zhou J, Zhi Q, Wu MY, Gong FR, Shen M, Liu L, Tao M, Shen B, Gu DM, Yu J, Xu MD, Gao Y, Li W. Ginsenoside Rg3 targets cancer stem cells and tumor angiogenesis to inhibit colorectal cancer progression in vivo. Int J Oncol, 2017; 52 (1):127-38.

Tseng CY, Lin CH, Wu LY, Wang JS, Chung MC, Chang JF, Chao MW. Potential combinational anti-cancer therapy in non-small cell lung cancer with traditional Chinese medicine Sun-Bai-Pi extract and cisplatin. PLoS One, 2016; 11(5):e0155469.

Tsukamoto S, Hirotsu K, Kumazoe M, Goto Y, Sugihara K, Suda T, Tsurudome Y, Suzuki T, Yamashita S, Kim Y, Huang Y, Yamada $\mathrm{K}$, Tachibana $\mathrm{H}$. Green tea polyphenol EGCG induces lipid-raft clustering and apoptotic cell death by activating protein kinase $\mathrm{C} \delta$ and acid sphingomyelinase through a $67 \mathrm{kDa}$ laminin receptor in multiple myeloma cells. Biochem J, 2012; 443(2):525-34.
Vandenabeele P, Galluzzi L, Vanden Berghe T, Kroemer G. Molecular mechanisms of necroptosis: an ordered cellular explosion. Nat Rev Mol Cell Biol, 2010; 11(10):700-14.

Wang B, Han Q, Zhu Y. Oxymatrine inhibited cell proliferation by inducing apoptosis in human lung cancer A549 cells. Biomed Mater Eng, 2015; 26:S165-72.

Wang B. Ancient books of CHM publishing house. The Yellow Emperor's Inner Canon, Beijing, China, 2003.

Wang H, Zhao L, Zhu LT, Wang Y, Pan D, Yao J, You QD, Guo QL. Wogonin reverses hypoxia resistance of human colon cancer HCT116 cells via downregulation of HIF- $1 \alpha$ and glycolysis, by inhibiting PI3K/Akt signaling pathway. Mol Carcinog, 2014; 53(Supplement 1):E107-18.

Wang X, Hao MW, Dong K, Lin F, Ren JH, Zhang HZ. Apoptosis induction effects of EGCG in laryngeal squamous cell carcinoma cells through telomerase repression. Arch Pharm Res, 2009; 32:1263-9.

Warburg O. On the origin of cancer cells. Science, 1956; 123:309-14.

Way TD, Lee JC, Kuo DH, Fan LL, Huang CH, Lin HY, Shieh PC, Kuo PT, Liao CF, Liu H, Kao JY. Inhibition of epidermal growth factor receptor signaling by Saussurea involucrata, a rare traditional Chinese medicinal herb, in human hormone-resistant prostate cancer PC-3 cells. J Agric Food Chem, 2010; 58(6):3356-65.

Wei LH, Lin JM, Xu W, Hong ZF, Liu XX, Peng J. Inhibition of tumor angiogenesis by Scutellaria barbata D. Don via suppressing proliferation, migration and tube formation of endothelial cells and downregulation of the expression of VEGF-A in cancer cells. J Med Plants Res, 2011; 5:3260-8.

Wiench B, Eichhorn T, Paulsen M, Efferth T. Shikonin directly targets mitochondria and causes mitochondrial dysfunction in cancer cells Evid-Based Compl Alt Med, 2012; 2012:Article ID 726025, 15.

Xi SY, Teng YH, Chen Y, Li JP, Zhang YY, Liu SL, Zou X, Zhou JY, Wu J, Wang RP, Jianpi Huayu Decoction inhibits proliferation in human colorectal cancer cells (SW480) by inducing G/G1-Phase cell cycle arrest and apoptosis. Evid-Based Compl Alt Med, 2015; 2015:Article ID 236506, 8.

Xiao W, Wu K, Yin M, Han S, Ding Y, Qiao A, Lu G, Deng B, Bo P, Gong W. Wogonin inhibits tumor-derived regulatory molecules by suppressing STAT3 signaling to promote tumor immunity. J Immunother, 2015; 38:167-84.

Xiao XY, Hao M, Yang XY, Ba Q, Li M, Ni SJ, Wang LS, Du $\mathrm{X}$. Licochalcone A inhibits growth of gastric cancer cells by arresting cell cycle progression and inducing apoptosis. Cancer Lett, 2011; 302(1):69-75.

Xu Z, Chen X, Zhong Z, Chen L, Wang Y. Ganoderma lucidum polysaccharides: immunomodulation and potential anti-tumor activities. Am J Chin Med, 2011; 39:15-27.

Yance DR, Jr, Sagar SM. Targeting angiogenesis with integrative cancer therapies. Integr Cancer Ther, 2006; 5:9-29.

Yang JY, Della-Fera MA, Rayalam S, Baile CA. Enhanced effects of xanthohumol plus honokiol on apoptosis in 3T3-L1 adipocytes. Obesity, 2008; 16(6):1232-8.

Yang P, Cartwright C, Chan D, Vijjeswarapu M, Ding J, Newman A. Zyflamend-mediated inhibition of human prostate cancer PC3 cell proliferation: effects on 12-LOX and $\mathrm{Rb}$ protein phosphorylation. Cancer Biol Ther, 2007; 6(2):228-36.

Ye B, Aponte M, Dai Y, Li L, Ho MC, Vitonis A, Edwards D, Huang TN, Cramer DW. Ginkgo biloba and ovarian cancer prevention: epidemiological and biological evidence. Cancer Lett, 2007; 251:43-52.

Yoo M, Shin J, Kim H, Kim J, Kang J, Tan AC. Exploring the molecular mechanisms of traditional Chinese medicine components using gene expression signatures and connectivity map. Computer Methods Programs Biomed, 2018; 174:33-40; doi:10.1016/j.cmpb.

Yoshida H, Okumura N, Kitagishi Y, Nishimura Y, Matsuda S Ethanol extract of Rosemary repressed PTEN expression in K562 culture cells. Int J Appl Biol Pharm Technol, 2011; 2:316-22.

Yu JS, Roh HS, Lee S, Jung K, Baek KH, Kim KH. Antiproliferative effect of Momordica cochinchinensis seeds on human lung cancer cells and isolation of the major constituents. Rev Bras Farmacogn, $2017 ; 27: 329-33$. 
Yun TK, Choi SY. Preventive effect of ginseng intake against various human cancers: a case-control study on 1987 pairs. Cancer Epidemiol Biomarkers Prev, 1995; 4:401-8.

Zhang L, Tian W, Kim S, Ding W, TongY, Chen S. Arsenic sulfide, the main component of realgar, a traditional Chinese medicine, induces apoptosis of gastric cancer cells in vitro and in vivo. Drug Des Devel Ther, 2014; 9:79-92.

Zhang LP, Jiang JK, Tam JW, Zhang Y, Liu XS, Xu XR, Liu BZ, He YJ. Effects of Matrine on proliferation and differentiation in K-562 cells. Leuk Res, 2001; 25:793-800.

Zhang S, Zhang Y, Zhuang Y, Wang J, Ye J, Zhang S, Wu J, Yu K, Han Y. Matrine induces apoptosis in human acute myeloid leukemia cells via the mitochondrial pathway and Akt inactivation. PLoS One, 2012; 7(10):e46853.

Zhang SY, Gu CH, Gao XD. A randomly double-blinded and multicentre study of chemotherapy assisted Yangzhengxiaoji capsule on treating primary hepatic carcinoma. J Diffic Compl Case, 2009; 8:461-4.

Zheng L, Zhang YM, Zhan YZ, Liu CX. Momordica cochinchinensis seed extracts suppress migration and invasion of human breast cancer ZR-75-30 cells via down-regulating MMP-2 and MMP-9. Asian Pac J Cancer Prev, 2014; 15(3):1105-10.
Zheng T, Que Z, Jiao L, Kang Y, Gong Y, Yao J, Ma C, Bi L, Dong Q, Zhao X, Xu L Herbal formula YYJD inhibits tumor growth by inducing cell cycle arrest and senescence in lung cancer. Sci Rep, 2017; $7: 4984$.

Zhou X, Seto SW, Chang D, Kiat H, Razmovski-Naumovski V, Chan K, Bensoussan A. Synergistic effects of chinese herbal medicine: a comprehensive review of methodology and current research. Front Pharmacol, 2016; 7:201.

\section{How to cite this article:}

Subramaniam M, Lim YM. Chinese herbal medicine exhibits anticancer properties via eight cancer hallmarks. J Appl Pharm Sci, 2020; 10(08):149-163. 